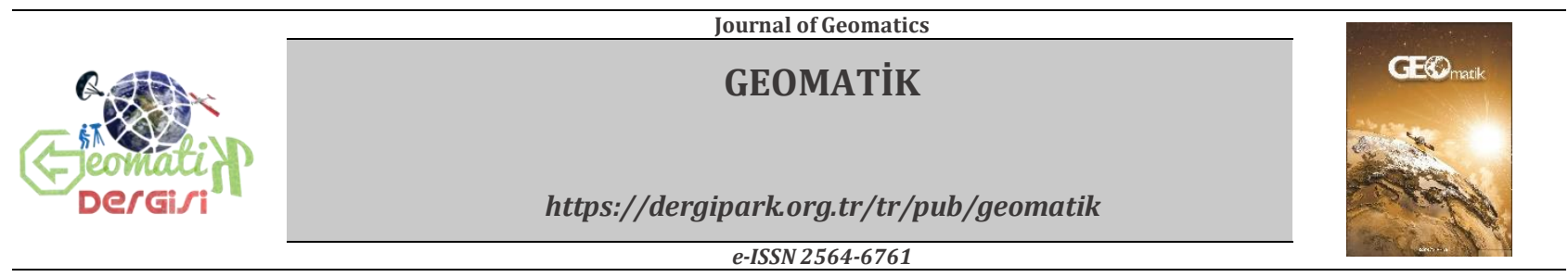

\title{
Göktürk-1 Uydu Görüntülerinin Pankeskinleştirme Performansının İncelenmesi
}

\author{
Ahmet Ünal*1, Ferruh Yıldız \\ ${ }^{1}$ Konya Teknik Üniversitesi, Mühendislik ve Doğa Bilimleri Fakültesi, Harita Mühendisliği Bölümü, Konya, Türkiye
}

\author{
Anahtar Kelimeler \\ Cözünürlük \\ Göktürk-1 \\ Görüntü Birleștirme \\ Pankeskinleștirme \\ Uydu Görüntüsü
}

\begin{abstract}
ÖZ
Ülkemizin ilk yüksek çözünürlüklü uydusu olan Göktürk-1 uydusundan alınan görüntülerinde kullanım alanlarına göre çok büyük faydalar sağlayacağı tartışılmazdır. $\mathrm{Bu}$ çalışmada farklı pankeskinleştirme yöntemleri karşılaştırılmış, seçilmiş bir örnek Göktürk-1 uydu görüntüsü 4 farklı programda yer alan toplam 23 algoritmada pankeskinleştirilmiş, elde edilen görüntülerin görsel olarak ve matematiksel ölçütlerle analizi yapılmıș ve Göktürk-1 uydu görüntüleri için en uygun pankeskinleștirme yöntemi belirlenmeye çalıșılmıștır. Bu kapsamda elde edilen bulgular görsel ve metrik olarak değerlendirilmiş, aynı algoritmaların farklı yazılımlarda farklı sonuçlar verdiği gözlemlenmiștir. Elde edilen görsel değerlendirmeler ıșığında Göktürk-1 uydu görüntülerini pankeskinleștirmek için; ERDAS yazılımında ERDAS Resolution Merge, Subtractive Resolution Merge ya da HCS Resolution Merge algoritmalarının, ENVI yazılımında NNDiffuse Pan Sharpening algoritmasının, HASAT yazılımında Brovey algoritmasının ve PCI yazılımında PANSHARP2 algoritmasının görsel olarak daha iyi sonuç verdiği gözlemlenmiştir. Pankeskinleștirme işlemleri sonucunda elde edilen görüntüler bu tarz çalışmalarda yaygın olarak kullanılan RMSE, RASE, CC, ERGAS ve QAVE metriklerine göre değerlendirilmiștir. Metrik değerlendirmeler için MATLAB programı kullanılmış ve ERGAS metriğinde "ENVI Color Normalized (Brovey) Sharpening" yöntemi, RMSE, CC, RASE ve QAVE metriklerinde ise "PCI-MRA" yöntemi daha bașarılı sonuçlar vermiştir.
\end{abstract}

\section{Investigation of Pansharpening Performance on Göktürk-1 Satellite Images}

\author{
Keywords \\ Resolution \\ Göktürk-1 \\ Image Fusion \\ Pansharpening \\ Satellite Image
}

\begin{abstract}
It is obvious that the images taken from Göktürk-1 satellite, which is the first high resolution satellite of our country, will provide great benefits in different areas according to its usage areas. In this study, different pansharpening methods are compared, a selected sample Göktürk-1 satellite image has been pansharpened with 23 algorithms in 4 different softwares, the images obtained are analyzed visually and mathematically and thus the most appropriate pansharpening method is tried to be determined for Göktürk1 satellite images. Findings obtained in this context were evaluated visually and metrically, and it was observed that the same algorithms gave different results in different software. In the light of the visual evaluations obtained, in order to sharpen Göktürk-1 satellite images; It has been observed that using ERDAS Resolution Merge, Subtractive Resolution Merge or HCS Resolution Merge algorithms in ERDAS software, NNDiffuse Pan Sharpening algorithm in ENVI software, Brovey algorithm in HASAT software and PANSHARP2 algorithm in PCI software is better result visually. The images obtained as a result of the pansharpening processes have been evaluated according to the RMSE, RASE, CC, ERGAS and QAVE metrics commonly used in such studies. The MATLAB program has been used for metric evaluations and the "ENVI Color Normalized (Brovey) Sharpening" method in the ERGAS metric and the "PCI-MRA" method in the RMSE, CC, RASE and QAVE metrics have been gave more successful results.
\end{abstract}




\section{GíRiş}

Dünya üzerindeki herhangi bir noktanın istenilen zamanda ve herhangi bir engele maruz kalmaksınız askeri istihbarat isteklerini karşılayabilecek şekilde yüksek çözünürlüklü görüntü elde edilmesine imkân tanıyacak, aynı zamanda kamu ve özel sektör tarafından ormanlık alanların kontrolü, imara aykırı yapılaşmanın takibi, doğal afetlerden sonra ihtiyaç duyulan hasar tespiti, ürün rekolte tespiti ve coğrafi harita verilerinin üretilmesi gibi faaliyet alanlarında da görüntü ihtiyacını karşılayacak bir uydu sisteminin tedarik edilmesi ihtiyacı Göktürk-1 uydu projesini ortaya çıkarmıştır.

Uydu görüntüleri kullanıcılara sunulmadan önce birçok görüntü işleme sürecinden geçirilmektedir. Yüksek mekânsal çözünürlüklü pankromatik görüntü ile multispektral (çok bantlı) görüntünün birleştirilmesi işlemi yani Pankeskinleștirme işlemi bu görüntü işleme adımlarının önemli bir parçasını oluşturmaktadır. Artan teknolojiye paralel olarak uydu teknolojisi de ilerlemiş buna bağlı olarak farklı yörüngelerde bulunan ve birbirinden değişik özelliklere sahip birçok uydu sistemleri geliștirilmiștir. Bu sistemlerin ortak amacı yeryüzüne ait verilerin toplanması, işlenmesi ve çeşitli amaçlarla kullanılabilmesinin sağlanmasıdır. Kısaca coğrafi verilerin elde edilişi uzaktan algılama bilimi içerisinde farklı algılayıcı ve sistemlerle sağlanmaktadır.

Pankeskinleştirme konusunda literatürde birçok çalışma mevcuttur. Genelde aynı ya da farklı uydu görüntülerinin birleștirilmesi suretiyle bir bölgeye ait detay bilgisini ön plana çlkararak görüntü yorumlama amaçlı çalışmalar yoğunluk kazanmaktadır (Abdikan, 2017).

En çok karşımıza çıkan çalışma ise; aynı uyduya ait PAN (Pankromatik) ve MS (Multi Spektral) görüntülerin birleştirilmesi suretiyle çözünürlüğü yüksek MS görüntü elde etme amacı güden çalışmalardır (Özendi ve ark., 2015).

Worldview-3 ve QuickBird uydu görüntüleri için en verimli sonuçların Gram-Schmidt ve UNB (Universty of New Brunswick - New Brunswick Üniversitesi) algoritmalarının uygulanması ile alındığı ancak metrik yöntemlerin, şehir, kırsal alan, dağlık veya ormanlık alanlara göre seçilen pankeskinleștirme metodunun farklı sonuçlar verebildiği ortaya konulmuştur (Snehmani ve ark.,2014).

Farklı SAR (Sentetik Açıklı Radar) görüntüleri ile SPOT-2 elektro optik uydu görüntüsü IHS (Intensty Hue Saturation - Yoğunluk Renk Doygunluk), Ehlers ve Brovey yöntemleriyle birleştirilmiş ve Ehlers yönteminin spektral açıdan da metrik açıdan da diğerlerinden iyi olduğu tespit edilmiştir (Abdikan, 2014).

RASAT görüntülerinden yapılan pankeskinleștirme çalışmasında en uygun sonuçların HCS (Hyperspherical Color Space Hiperküre Renk Uzayı) ve Opt.HPF (Optimized High
Pass Filter - Optimize Edilmiş Yüksek Geçirgen Filtre) yöntemleri ile alındığını gözlemlenmiştir (Açlkgöz, 2015).

Görüntü füzyon yöntemleri QuickBird uydu görüntüleri üzerinde ve matematiksel sonuçları ise MATLAB programı kullanılarak ortaya konulmuş, optimizasyon algoritması olan parçacık sürü optimizasyonunun pankeskinleştirme teknikleri için iyi bir sonuç ortaya koyduğu ve istatistiksel olarak da iyi sonuçlar verdiği gözlemlenmiştir (Abas, 2015).

Pleiades 1-A görüntülerinin pankeskinleştirme performansı incelemiș, nicelik olarak Brovey, nitelik olarak IHS algoritmaları ile yapılan görüntülerin daha iyi sonuçlar verdiği gözlemlenmiştir (Özendi, 2014).

IKONOS, Geoeye ve Worldview uydu görüntüleri MS ve Pankromatik görüntülerin füzyonunu esas alan pankeskinleștirme yöntemleri incelenmiş, kullanılan algoritmalar içerisinde SFIM (Smoothing Filter Intensity Modulation Pürüzsüzleștirici Filtre Yoğunluğu Modülasyonu) metodunun özgün çakıştırma stratejisi ile iyileştirilerek birleştirilmiştir (Sümengen, 2012).

Başka bir çalışmada RASAT uydusuna ait Mersin, İstanbul ve Sinop görüntüleri 17 farklı algoritma ile pankeskinleştirilmiş matematiksel olarak RMSE (Root Mean Square Error), CC (Correlation Coefficient), SAM (Spectral Angular Mapper), ERGAS (Erreur Relative Globale Adimensionnelle de Synthèse), PSNR (Peak Signal to Noise Ratio - En Yüksek Sinyal Hata Oranı), SSIM (Structural Smilarity Index - Yapısal Benzerlik Analizi) ve UIQI (Universal Image Quality İndex Evrensel Görüntü Kalite İndeksi) yöntemleri ile sonuçlar kıyaslanmıș ve MTF (Modulation Transfer Function - Modülasyon Transfer Fonksiyonu) - GLP (Generalised Laplacian Pyramid - Genelleştirilmiş Laplacian Piramidi) - HPM (High Pass ModulationYüksek Geçiren Modülasyon) yöntemi ile yapılan görüntünün tüm metriklerde en iyi sonuçları verdiği gözlemlenmiştir (Kahraman, 2017).

Pleiades 1-A Zonguldak test alanı görüntüsü üzerinde PCA (Principal Component Analysis), IHS ve Brovey algoritmaları ile pankeskinleştirme işlemi yapılmış ormanlık, şehir ve düz alanlarda ayrı ayrı karşılaştırılmış ve elde edilen sonuçlar CC, ERGAS, RASE (Relative Average Spectral Error), SAM ve RMSE matematiksel ölçütleri ile incelenmiştir. Brovey yöntemi CC, ERGAS ve SAM metriklerinde en iyi sonucu vermiş, IHS yöntemi RMSE ve RASE metriklerinde başarılı olmuştur. Ayrıca düz ve kentsel alanlarda görsel olarak en doğal sonucu IHS yöntemi ile yapılan görüntüler verirken ormanlık alanda Brovey yöntemi ile yapılan görüntünün en doğal sonucu verdiği gözlenmiştir (Topan, 2016).

QuickBird ve Worldview-3 görüntülerinin pankeskinleștirme performansları ayrıntılı bir şekilde incelenmiş, QuickBird uydularında en iyi sonucun Gram - Schmidt ve UNB olduğu ortaya konulmuştur (Gore, 2016).

London Tower köprüsüne ait WorldView-2 görüntüsü Gram - Schmidt yöntemi ile 
pankeskinleştirilmiş ve sonucunda görüntünün belli bir bölgesinin hızlı pankeskinleştirmeye ihtiyaç duyulabileceği çalışmalarda başarılı sonuçlar vereceği değerlendirilmiştir (Maurer, 2013).

İstanbul, Trabzon ve Osmancık (Çorum) bölgelerine ait RASAT uydu görüntüsü ile yapılmış pankeskinleştirme performans analizlerinde, RASAT uydu görüntüleri kullanılarak yapılacak pankeskinleştirmede yöntem olarak haritacılık şehir planlama gibi uygulamalar için HPF (High Pass Filter - Yüksek Geçirgen Filtre) yönteminin, daha yüksek doğruluğa sahip tarım ve çevre uygulamaları için ise HCS (Hyperspherical Color Space - Hiperküre Renk Uzayı) yönteminin tercih edilmesinin gerektiği ortaya konulmuştur (Teke, 2014).

Benzer şekilde WorldView-3 uydu görüntüsüne ait Almanya'daki yeşil alan ve Libra şehir alanlarında IHS ve Brovey algoritmaları ile bir analiz yapılmıştır (Parente, 2017). DubaiSat-1 Dubai görüntüsünde 9 ayrı pankeskinleştirme algoritması ile gerçekleştirilen pankeskinleştirme sonuçları görsel olarak incelenmiş ve 4 farklı matematiksel ölçüt ile değerlendirme yapılmıştır (Basaeed, 2013). Wavelet dönüşümü ile Landsat-7 uydusuna ait görüntünün farklı bant varyasyonları ile analizleri yapılmıș (Czaja, 2014), QuickBird uydu görüntüsünün çeşitli bant varyasyonları 10 farklı algoritma ile performans analizi yapılmıştır. (Despini, 2014)

PC (Principle Component), IHS, Gram - Schmidt, Ehlers ve Yun Zhang yöntemleri ile farklı görüntüler pankeskinleștirilmiş ve görüntüler nesne yönelimli sınıflandırma açısından ayrıca irdelenmiş, Landsat8, Kompsat-3 ve WorldView-2 görüntülerinin keskinleştirilmesi sonucunda Ehlers dişındaki tüm yöntemlerin yeterli doğrulukta sonuçlar verdiği değerlendirilmiştir (Özdemir, 2017).

$\mathrm{Bu}$ çalışmada örnek bir Göktürk-1 uydu görüntüsü üçü ticari, birisi ise yerli ve milli olmak üzere toplamda 4 yazılım üzerinde 23 farklı yöntem ile pankeskinleştirilmiş ve elde edilen görüntüler görsel ve matematiksel olarak kıyaslanmıștır.

\section{1. Çalışma Alanı ve Veriler}

GÖKTÜRK-1 Uydu Projesi sözleşmesi, bugünkü adıyla Cumhurbaşkanlığı Savunma Sanayii Başkanlığı ile İtalyan Telespazio S.p.A. firması arasında 2009 yılı Temmuz ayında imzalanmıştır. Sözleşme kapsamında GÖKTÜRK-1 Uydusunun bazı uçuş bileşenlerinin TUSAŞ tarafından üretilmesi planlanmıştır. Uydu, Avrupa Uzay Ajansına ait VEGA roketi ile 05 Aralı 2016 tarihinde Fransız Guyanası'ndan Türkiye saati ile 16:51.44'de fırlatılmış ve yörüngeye başarıyla yerleştirilmiştir. Göktürk-1 sisteminin şartlı nihai kabulü 4 Aralık 2018 tarihinde gerçekleştirilmiş ve resmi olarak tamamen Hv.K.K.lığının kontrolüne geçmiştir. Proje çerçevesinde bir adet $0,5 \mathrm{~m}$ çözünürlüklü ElektroOptik Uydu, bir adet Ana Yer İstasyonu ve bir adet Mobil Yer İstasyonu temin edilmiştir.

Göktürk-1 Uydusuna ait ana istasyon ile mobil istasyon Şekil 1'de gösterilmektedir.

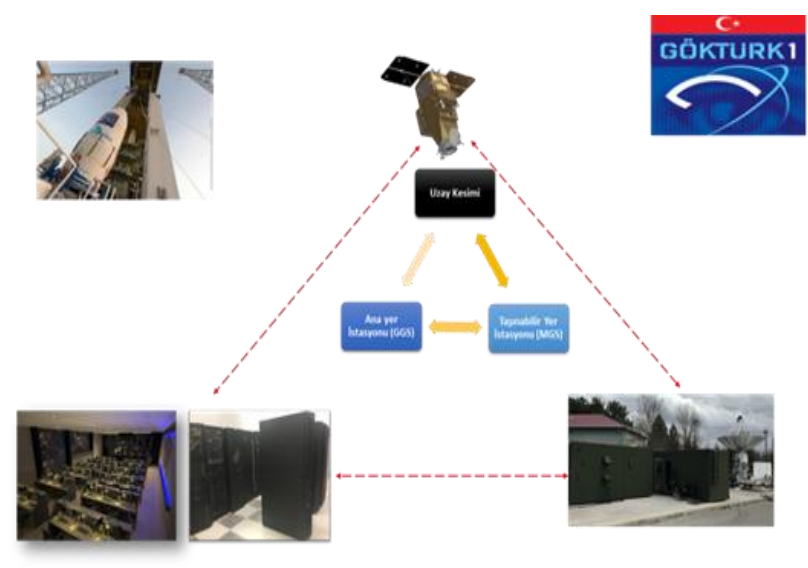

Şekil 1. Göktürk-1 Yer İstasyonu

Göktürk-1 uydusu nokta, şerit, geniş alan ve stereo görüntüleme modlarında çekim işlemi gerçekleştirebilmektedir. Nokta (spot) görüntüleme işleminde görüntünün genişliği ve uzunluğu $15 \mathrm{~km} * 15 \mathrm{~km}$, şerit görüntülemede ise görüntünün genişliği ve uzunluğu en fazla $15 \mathrm{~km} * 780 \mathrm{~km}$ 'dir. Göktürk-1 uydusu yörünge istikametine ek olarak doğu - batı ve kuzey - güney istikametinde çekim yapabilme kabiliyetine ve mevcut yer istasyonları ile günlük en fazla 902 spot görüntü indirme ve işleme kapasitesine sahiptir. Göktürk-1 uydusunun dünya etrafındaki bir turu yaklaşık 98 dakikadır. Aynı noktanın tekrar çekimi için ihtiyaç duyulan zaman ise 2 ila 3 gün arasındadır. Göktürk-1 uydusu biri PAN (siyah-beyaz) ve dördü MS (Multi - Spektral: Red - Green - Blue - Near IR) olmak üzere toplam beş adet bantta görüntüleme yapabilmektedir. Siyah Beyaz bandın çözünürlüğü 0.50 m iken multispektral bantların çözünürlüğü 2.0 m’dir (Gürçay, 2019).

Türk Silahlı Kuvvetleri envanterinde Göktürk-1 ve Göktürk-2 olmak üzere iki adet uydu vardır. İkisi de keşif gözetleme uydusudur. $\mathrm{Bu}$ uydular arasındaki fark, PAN bantta Göktürk-1 0,5 m yer örnekleme aralığına (GSD - Ground Sampling Distance) sahipken Göktürk-2 ise 2,5 m GSD'ye sahiptir. İlerleyen dönemlerde SAR (Sentetik Açıklı Radar) uydularının da envantere girmesi beklenilmektedir.

Göktürk-1 Uydusunun teknik özellikleri Tablo1'de sunulmuştur.

Göktürk-1 uydu ömrü boyunca görüntülerinin yatay konumsal doğruluk değerinin $10 \mathrm{~m}$ (GCP'siz) ve düşey konumsal doğruluk değerinin de $20 \mathrm{~m}$ (GCP'siz) olması beklenmektedir. Tek bir GCP ile söz konusu doğruluk değeri ise 2 m.den daha iyi olacaktır (Gültekin,2019). 
Tablo 1.Göktürk-1 Uydusu Teknik Özellikleri

\begin{tabular}{|c|c|c|}
\hline Özellikler & \multicolumn{2}{|l|}{ Göktürk-1 } \\
\hline Yörünge Tipi & \multicolumn{2}{|c|}{ Güneș Eșzamanlı } \\
\hline Yörünge İrtifası & \multicolumn{2}{|l|}{$681 \mathrm{~km}$} \\
\hline Eğim Açısı & \multicolumn{2}{|l|}{$98,11^{\circ}$} \\
\hline Yörünge Hızı & \multicolumn{2}{|l|}{$7,51 \mathrm{~km} / \mathrm{sn}$} \\
\hline Periyot & \multicolumn{2}{|l|}{$98 \mathrm{dk} 11 \mathrm{sn}}$. \\
\hline Spot Boyutu & \multicolumn{2}{|l|}{$15 \times 15 \mathrm{~km}$} \\
\hline Șerit Genișliği & \multicolumn{2}{|l|}{$15 \mathrm{~km}$} \\
\hline Şerit Uzunluğu & \multicolumn{2}{|c|}{$\begin{array}{llr}780 \quad \mathrm{~km} & \text { (tek geçiște } \\
14.300 \mathrm{~km} & \text { (azami } & \text { çekim } \\
\text { kabiliyeti) } & & \end{array}$} \\
\hline Uydu Kütlesi & \multicolumn{2}{|c|}{1061 kg (yakıt dâhil) } \\
\hline $\begin{array}{l}\text { GSD (Ground } \\
\text { Sampling Distance) }\end{array}$ & \multicolumn{2}{|c|}{$0,5 \mathrm{~m}$ PAN - $2 \mathrm{~m} \mathrm{RGB}$} \\
\hline $\begin{array}{l}\text { Görüntü Kalitesi } \\
\text { (NIIRS-NATO } \\
\text { Image } \\
\text { Internretahilitv }\end{array}$ & \multicolumn{2}{|l|}{ NIIRS 5 (PAN) } \\
\hline $\begin{array}{l}\text { Radyometrik } \\
\text { Cözünürlük }\end{array}$ & \multicolumn{2}{|l|}{ 12-Bit } \\
\hline $\begin{array}{l}\text { Konumsal } \\
\text { Doğruluk }\end{array}$ & \multicolumn{2}{|c|}{$\begin{array}{l}\text { Ortalama } \\
\text { Yatay olarak } \\
10 \text { m (GCP'siz), } 2 \text { m (GCP'li) ** } \\
\text { Düşey olarak } \\
20 \text { m (GCP'siz), } 3 \text { m (GCP'li) }\end{array}$} \\
\hline $\begin{array}{l}\text { Uydu (On-Board) } \\
\text { Depolama }\end{array}$ & \multicolumn{2}{|c|}{192 Gbyte } \\
\hline $\begin{array}{l}\text { Yer İstasyonu } \\
\text { (Ground Station) } \\
\text { Debolama }\end{array}$ & \multicolumn{2}{|l|}{6 PByte } \\
\hline Spektral Bantlar & \multicolumn{2}{|l|}{ PAN, RGB, NIR } \\
\hline $\begin{array}{l}\text { Günlük Yörünge } \\
\text { Savısı }\end{array}$ & \multicolumn{2}{|l|}{$14-15(14,7)$} \\
\hline \multirow{2}{*}{$\begin{array}{l}\text { Ana/Yedek } \\
\text { İstasyon }\end{array}$} & Ana İstasyon & $\begin{array}{l}\text { GGS } \\
\text { (Ahlatlıbel) }\end{array}$ \\
\hline & $\begin{array}{l}\text { Yedek } \\
\text { İstasyon }\end{array}$ & $\begin{array}{l}\text { MGS } \\
\text { (Ahlatlıbel) }\end{array}$ \\
\hline Anten Takip Açısı & \multicolumn{2}{|l|}{$\begin{array}{l}\text { GGS } 5^{0} \\
\operatorname{MGS} 10^{0}\end{array}$} \\
\hline LTAN & \multicolumn{2}{|l|}{$10: 30$} \\
\hline Haberleșme & \multicolumn{2}{|c|}{ X-Band / 620 Mbps } \\
\hline Bantları / Hızları & \multicolumn{2}{|c|}{ S-Band / 1,6 Mbps } \\
\hline İletişim Konisi & \multicolumn{2}{|l|}{$4600 \mathrm{~km}$} \\
\hline $\begin{array}{l}\text { İletişim } \\
\text { Konisinden }\end{array}$ & \multicolumn{2}{|l|}{$4-5$} \\
\hline $\begin{array}{l}\text { Görüntüleme } \\
\text { Sıklığı }\end{array}$ & \multicolumn{2}{|c|}{$\begin{array}{l}2-3 \text { gün }\left( \pm 30^{\circ} \text { yönelme }\right. \\
11 \text { gün }\left( \pm 5^{\circ} \text { yönelme açısıyla }\right)\end{array}$} \\
\hline Tasarım & \multicolumn{2}{|l|}{7 yll 3 ay } \\
\hline Yükleniciler & \multicolumn{2}{|c|}{ Telespazio S.p.A./İtalya } \\
\hline Firlatma Tarihi & \multicolumn{2}{|l|}{ 05.Ara.16 } \\
\hline Firlatma Yeri & \multicolumn{2}{|c|}{ Fransız Guvanası-Kourou } \\
\hline
\end{tabular}

Gürçay (2019) yapmış olduğu çalışmada GÖKTÜRK-1 Uydusu Radyometrik ve Geometrik Kalibrasyon Faaliyetlerini anlatmıștır ayrıca Gültekin (2019) Uydu Görüntülerinde Geometrik
Doğruluk: Test Yöntemleri ve Göktürk-1 Performans Değerlendirmesi konulu makalesinde Göktürk-1 uydusuna ait geometric doğrulukları incelemiștir. Bu kapsamda Göktürk-1 uydu görüntülerine yönelik temel ve ileri seviye işlemleri tanımlayan (Seviye 0 - Seviye 6) 7 adet görüntü seviyesi mevcuttur. Göktürk-1 uydusu görüntü seviyeleri;

- Seviye 0(L0): İşlenmemiş görüntü (Ham Görüntü).

- Seviye 1(L1): Radyometrik Düzeltmesi Yapılmış Görüntü (detektör hataları, gürültü ve bulanıklık giderme işlemi yapılmış görüntü).

- Seviye 2A(L2A): Geometrik Düzeltmesi Yapılmış Görüntü (dünyanın eğikliğinden ve yöneliminden kaynaklı hataların giderilmesi ile oluşturulan görüntü).

- Seviye 2B(L2B): L2A seviye görüntüyü Georektifiye ederek elde edilmiş görüntü.

- Seviye 3A(L3A): Ortofoto yapılan görüntü.

- Seviye 3B(L3B): YKN kullanılarak Ortofoto yapılan görüntü.

- Seviye 4(L4): Stereo görüntü çiftlerinden oluşturulan Sayısal Yükseklik Modeli.

- Seviye 5(L5): Mozaikleme işlemi uygulanarak elde edilen görüntü.

- Seviye 6(L6): Sinıflandırılmış görüntü. Görüntü seviyeleri incelendiğinde bunlardan L0, L1 ve L2 seviye görüntüler temel seviye görüntüler olarak adlandırılmakta, L3, L4, L5 ve L6 seviye görüntüler ise ileri seviye görüntüleri oluşturmaktadir.

$\mathrm{Bu}$ çalışmada Spot olarak 03 Ekim 2018 tarihinde çekilmiş bir Göktürk-1 Ankara uydu görüntüsü üçü ticari, birisi ise yerli ve milli olmak üzere toplamda 4 yazılım üzerinde 23 farklı Pankeskinleștirme metodu ile Pankeskinleștirilmiş ve elde edilen görüntüler görsel ve matematiksel olarak kıyaslanmıştır. Bu çalışmadaki gaye Göktürk1 uydu görüntüleri için literatürde yer alan ve geçerliliği kabul görmüş yaygın pankeskinleștirme algoritmaları içerisinden hangisinin Göktürk-1 uydu görüntüleri için daha iyi sonuç vereceğinin ortaya koyulmasıdır.

Uygulamada kullanılan uydu görüntüsü 03 Ekim 2018 tarihinde saat 07:40'da 21.72 derecelik açı ile Göktürk-1 uydusu ile çekilmiş olan Ankara bölgesine (Şekil 1) ait $15 \mathrm{~km}^{*} 15 \mathrm{~km}^{\prime}$ lik spot bir görüntüdür. Görüntü 7 Ocak 2019 tarihinde temel seviyede (Level 0'dan Level 2'ye) ișlenmiștir.

Pankeskinleştirme işlemi kullanılan 15 km*15 km'lik görüntünün tamamına uygulanmıştır. Dolayısı ile bu kadar büyük boyutlu verilerle işlem yapıldığından analizler hem zaman almış hem de programlar işlemleri tamamlamada zorlanmıştır. Görüntü seçimi yapılırken kasıtlı olarak eğik alım açllı görüntü seçilmiş ve işlemlerde karşılaşılabilecek zorluklar test edilmek istenmiştir. Tüm işlemlerde görüntünün tamamı kullanıldığı için hem verileri depolamada hem de kıyaslama işlemlerinde oldukça zorluklarla karşılașılmıştır.

Çalışma alanının 15km*15km'lik tüm kısmını da içeren genel görsel Şekil 2'de sunulmuștur. 


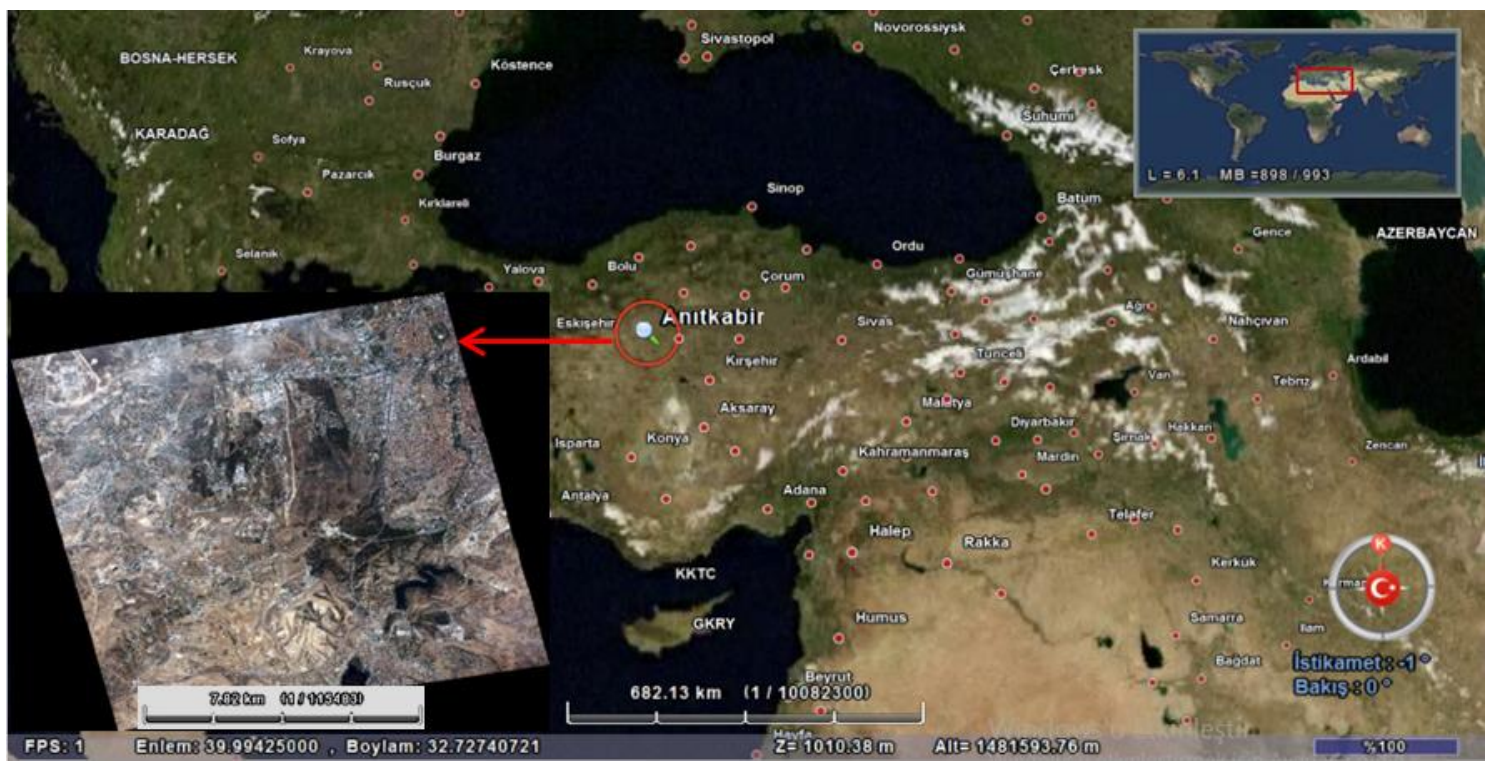

Şekil 2. Çalışma Alanı

\section{METHOD}

Günümüzde ticari olarak üretilen Coğrafi Bilgi Sistemi ya da görüntü ișleme yazılımlarının hepsinde çeșitli pankeskinleștirme algoritmaları vardır. Bunlardan bazlları tek bir algoritma olabileceği gibi bazılarında birden çok dönüşüm algoritmasının programa kombine șekilde tanıtılması suretiyle daha iyi sonuçlar vermesi sağlanmıştır. Örneğin $\mathrm{New}$ Brunswick Üniversitesi, Jeodezi ve Geomatik Mühendisliği Bölümü (University of New Brunswick - UNB), Kanada'da Prof.Dr. Yun Zhang tarafindan yapılan birçok çalışma ile UNB algoritması geliştirilmiş PCI programına tanıtılmıştır. Ayrıca çeşitli uydu görüntüleri için programın yardım kısmına band kombinasyonları ilave edilmiștir. Çalışmada kullanılan PCI 2018 (Şekil 3), ENVI 5.5 (Şekil 4) ve ERDAS Imagine 2018 (Şekil 5) yazılımlarında çok sayıda pankeskinleștirme algoritması mevcuttur. $\mathrm{Bu}$ algoritmalar tek bir algoritma olabileceği gibi bazı uydu görüntülerinin bazı programların farklı algoritmalarında değișik sonuçlar verdiği literatürde yapılan çalışmalar ile ortaya konulmuştur (Gore, 2016).

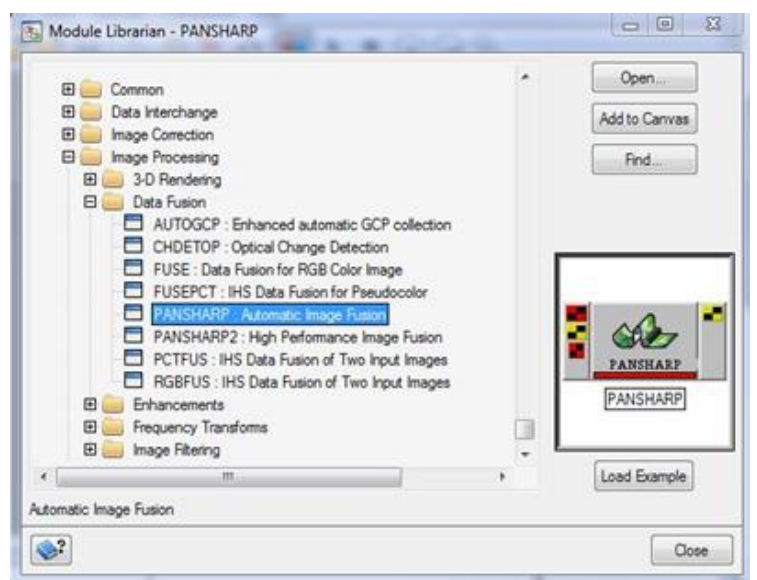

Şekil 3.PCI yazılımı pankeskinleștirme sekmeleri

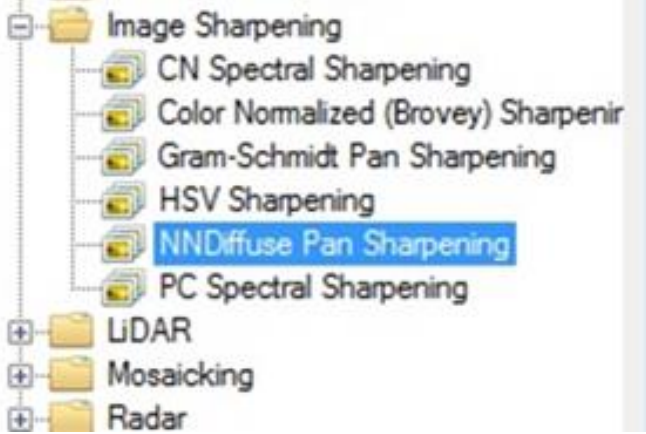

Şekil 4.ENVI yazılımı pankeskinleștirme sekmeleri

$$
\begin{aligned}
& \text { ה NNDiffuse Resolution Merge } \\
& \text { * Subtractive Resolution Merge } \\
& \text { - Subtractive Resolution Merge (Legacy) } \\
& \text { w HPF Resolution Merge } \\
& \text { - Modified IHS Resolution Merge } \\
& \text { * Wavelet Resolution Merge } \\
& \text { * Ehlers Fusion } \\
& \text { * HCS Resolution Merge } \\
& \text { * Resolution Merge } \\
& \text { * Projective Resolution Merge }
\end{aligned}
$$

Şekil 5.ERDAS yazılımı pankeskinleștirme sekmeleri

Yukarıda sözünü ettiğimiz ticari firmalarda kendi yaptıkları çalışmalar sonucunda hangi amaçla yapılan pankeskinleștirme işleminde hangi algoritmalarını kullanmanız gerektiği ile ilgili yardım menülerinde ipuçları vermekle birlikte kendi yaptıkları algoritmaların hangi uydu görüntülerinde (Pleiades, Worldview, Quickbird vs.) ya da hangi alanda (kırsal, şehir içi, ormanlık vs.) başarılı olabileceği konularında fikir vermeye çalışmışlardır. Örneğin "İkonos uydu görüntülerinin pankeskinleştirme işlemi sonucunda yapılan değerlendirmelerinde, spektral açıdan en iyi 
sonuçların ise Modified IHS dönüşüm yönteminden elde edildiği" ortaya konulmuştur (Ayhan, 2017).

Hâlihazırda kullanılan yazılımlardan PCI ve ERDAS yazılımları Göktürk-1 uydu görüntülerini sistemlerine tanıtmışlar, ENVI ve ESRI tarafından da tanıtma işlemleri devam etmektedir.

$\mathrm{Bu}$ ticari algoritmaların dışında uydu, keşif uçakları ve insansız hava araçlarından elde edilen yüksek çözünürlüklü görüntülerin işlenmesi ve analiz edilmesi, detayların otomatik olarak tespit edilmesi, hareketli ve hareketsiz nesnelerin görüntülenmesi ve tüm bu çalıșmaların Hava Kuvvetleri Bilgi Sistemleri ile entegreli ve otomatik olarak gerçekleştirilmesi amaçlanarak ARGE Projesi olarak Görüntü Analizi ve Otomatik Hedef Alglama amacı başlatılan, yerli ve milli bir yazılım olarak geliştirilen HASAT yazılımı da içerisinde 3 adet pankeskinleștirme algoritması barındırmaktadır. Ticari yazllımların yanında HASAT yazılımı da kullanılarak değerlendirmelere dâhil edilmiştir.

\subsection{Pankeskinleștirme Yöntemleri}

Çalışma kapsamında HASAT, ENVI, ERDAS IMAGINE ve PCI 2018 yazılımlarının içerisinde bulunan pankeskinleștirme metodları kullanılmıș, hepsinden elde edilen sonuçlar görsel ve metrik olarak analiz edilmiştir. Ancak çalışmada ENVI programı CN Spectral Sharpening metodu ile ERDAS programı Ehlers Fusion metodlarından anlamlı sonuçlar elde edilememiştir. Çalışma kapsamında yapılan araştırmada CN Spectral Sharpening metodunun görüntüye bağlı olarak çalışmadığı sonucuna ulaşılmıştır. ERDAS programı Ehlers yönteminde ise donanıma bağlı performans yetersizlikleri nedeni ile sonuca ulaşılamadığı değerlendirilmiştir. Yapılan çalışma daha önce de vurguladığı üzere görüntünün bir bölümünde değil tamamı üzerinde sürdürülmüş, sonuçları küçük kesitler üzerinde gösterilmeye çalışılmıştır. Kullanılan programların menülerine eklenen yaygın pankeskinleștirme metodları aşağıda kısaca anlatılmıştır.

\subsubsection{Brovey yöntemi}

Dönüşüm, renklilik dönüşümünü esas alan bir yöntem olup MS görüntünün parlaklık bilgisinin PAN görüntü ile modüle edilerek MS görüntüye uygulanmasını esas alan bir yöntemdir.

$$
\begin{aligned}
R_{\text {yeni }} & =\frac{R}{(R+G+B) / 3} * P A N \\
G_{y e n i} & =\frac{G}{(R+G+B) / 3} * P A N \\
B_{\text {yeni }} & =\frac{B}{(R+G+B) / 3} * P A N
\end{aligned}
$$

R: Red (Kırmızı), G: Green (Yeşil), B: Blue( Mavi), PAN: Pankromatik olarak tanımlanır.

$$
\begin{aligned}
& l_{i=\frac{P X N}{\sum_{i=1}^{N} M_{i}}} \\
& l_{=} \sum_{i=1}^{N} l_{i}
\end{aligned}
$$

$\mathrm{N}$ bant sayısını, $l_{i}$ MS görüntünün i. bandına karşıllk gelen yüksek mekânsal ve spektral çözünürlüklü görüntüsünü, $M_{i}$ ise pankromatik görüntüye göre ölçeklendirilmiş MS görüntünün i. bandını ifade etmektedir.

\subsubsection{IHS (Intensity-Hue-Saturation) yöntemi}

$\mathrm{Bu}$ yöntemde öncelikle renkli bantlar IHS renk uzayına dönüștürülür. Çözünürlüğü düşük yoğunluk bandı ile çözünürlüğü yüksek PAN bandı yer değiştirilir. Bu işlem sonucunda elde edilen görüntü yeniden RGB renk uzayına dönüştürülür. Bu görüntü kenar bilgisini oldukç a yeterli bir biçimde korur. Dolayısı ile görüntüde spektral bozulmalar oluşmaktadır (Teke, 2014).

MS görüntünün her bir bandı ölçeklendirilmiş pankromatik görüntü ile toplanır, daha sonra bu toplam değerden yoğunluk değeri çlkartılarak birleștirilmiş görüntüde karşılık gelen bandı hesaplanır. IHS yöntemi Şekil 6 ile gösterilmiștir.

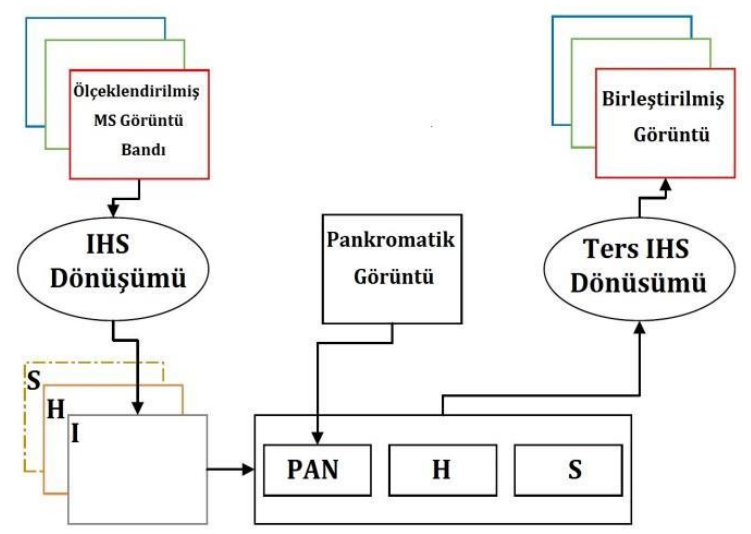

Şekil 6. IHS yöntemi diyagramı

\subsubsection{PCA (Principle Component Analysis) yöntemi}

Temel birleşen analizi dönüşümü yöntemi, ilintili multispektral bantları temel bileşenlere ayırır (Her bir temel bileşen bağımsızdır). Diğer bileșenlere göre daha yüksek varyans değerine sahip olması sebebi ile ilk bileşen PAN görüntüye benzemektedir, bu sebeple PAN görüntü ilk temel bileșen yerine geçirilir. Sonra ters temel bileșen analizi (PCA) dönüşümü yapılarak pankeskinleștirilmiş görüntü elde edilir. Elde edilen görüntü PAN görüntüye ait daha yoğun bilgi taşıdığından matematiksel olarak iyi sonuç verir ancak renk bilgisini yeterince koruyamaz. 
MS görüntülerinin pankromatik görüntüye göre ölçeklendirilmesi sonrasında elde edilen ölçeklendirilmiş görüntülerin temel bileșenlerine ayrılması işlemi gerçekleştirilir. PAN görüntünün birinci temel bileșene göre normalleştirilmesinden sonra birinci temel bileșen yerine normalleștirilmiş pankromatik görüntünün kullanılması işlemi ve ters temel bileșenler analizi uygulanarak füzyonun gerçekleștirilmesi sağlanır. Dönüşüm işlemi Șekil 7'de gösterilmiştir.

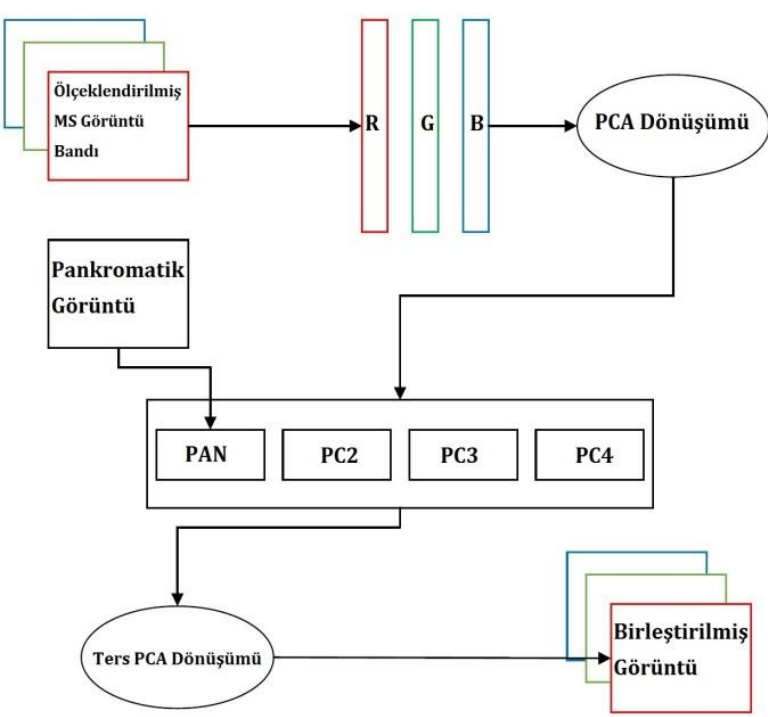

Şekil 7. PCA yöntemi diyagramı

\subsubsection{HCS (Hyperspherical Color Space) yöntemi}

RGB renk uzayından hiperküre renk uzayına dönüșüm; n-boyutlu kartezyen uzayından n-boyutlu hiperküre uzayına dönüştürülmesi esasına dayanan bir yöntemdir. N adet bant barındıran MS görüntü için HCS dönüşümü aşağıdaki denklemler sonucunda elde edilir. İlk bileșen yoğunluk değerini temsil etmektedir ve HCS üzerinde $\mathrm{N}-1$ adet açı hesaplanır.

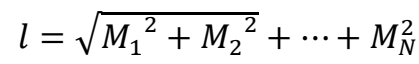

$\varphi_{1=} \tan ^{-1}\left(\frac{\sqrt{M_{N}^{2}+M_{N-1}^{2}+\cdots+M_{2}^{2}}}{M_{1}}\right)$

$\varphi_{N-2=} \tan ^{-1}\left(\frac{\sqrt{M_{N}^{2}+M_{N-1}^{2}}}{M_{N-2}}\right)$

$\varphi_{N-1=} \tan ^{-1}\left(\frac{M_{N}}{M_{N-11}}\right)$

$M_{i}$ RGB renk uzayındaki i. bileșeni temsil etmektedir. Geri dönüşüm ise aşağıdaki formüller ile hesaplanır.

$M_{1}=l \cos \varphi_{1}$
$M_{2}=l \sin \varphi_{1} \cos \varphi_{2}$

$M_{N-1}=l \sin \varphi_{1} \sin \varphi_{2} \ldots \sin \varphi_{N-2} \cos \varphi_{N-1}$

$M_{N}=l \sin \varphi_{1} \sin \varphi_{2} \ldots \sin \varphi_{N-2} \sin \varphi_{N-1}$

Hiperküre renk uzayına dönüșümde $\varphi i$ açıları ton ve renk değerlerini ifade etmektedir. I renk yoğunluğu bileşeni ise kürenin yarıçapını ifade etmektedir. HCS ortamına görüntü aktarıldıktan sonra renk değeri değişmeden yoğunluk ölçeklendirilebilmektedir. HCS ortamına dönüșüm herhangi bir doğal renk uzayından yapılabilmektedir. Şekil 8'de HCS renk uzayı küresel düzlemde gösterilmiştir.

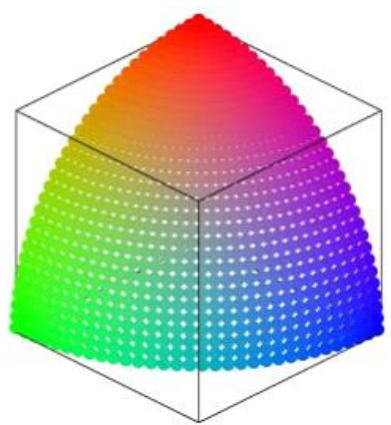

Şekil 8.HCS renk uzayı

\subsubsection{Wavelet dönüşüm yöntemi}

$\mathrm{Bu}$ yöntemde MS ve PAN görüntülere Ayrık Dalgacık Dönüşümü uygulanmak suretiyle işleme bașlanır. Bu dönüșümün temel mantığı Discrete Wavelet Transform yani Ayrı Dalgacık Dönüşümünün uygulanmasıdır. Bu işlem yapıldıktan sonra PAN görüntüde bulunan düşük frekanslı kısım çıkarılarak yerine MS görüntüde bulunan yüksek frekanslı kısım eklenir. Sonrasında ters dalgacık dönüșümü uygulanarak pankeskinleșmiș görüntü elde edilir. Bu dönüşüm uzamsal olarak iyi sonuçlar vermemesine rağmen renk bilgisini korumakta oldukça iyidir (Teke, 2014).

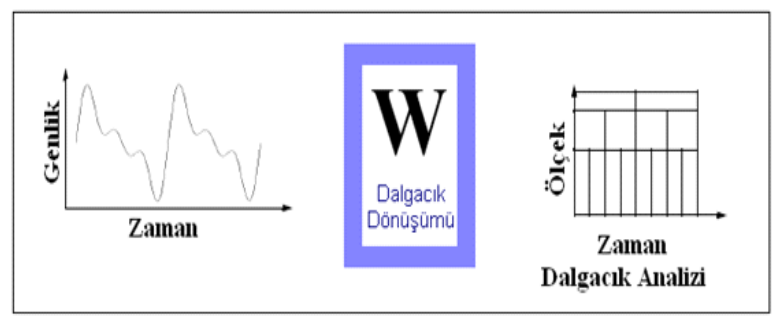

Şekil 9.Dalgacık dönüşümü

Wavelet Transform literatürde Multi Resolution Area (MRA) adı altında da incelenmektedir. Çoklu çözünürlük alanı olarak dilimize geçmiș olan bu yöntemde çözünürlüğü yüksek olan PAN görüntü düşük çözünürlüklü dalgacık katsayılarına dönüştürülür. Sonra MS görüntüde de aynı işlem uygulanarak dalgacık dönüşümü yapılır. MS görüntünün dalgacık katsayıları ile PAN görüntüden 
elde edilen dalgacık dönüşüm katsayıları yer değiștirilir ve ters dalgacık dönüșümü görüntüye uygulanır ve bu sayede çözünürlüğü yüksek MS görüntü elde edilir (Sümengen, 2012).

\subsubsection{HPF (High Pass Filter) yöntemi}

Yüksek Geçiren Süzgeç (High Pass Filter-HPF) yönteminde, MS ve PAN görüntülere oranları ölçüsünde filtreler seçilerek (9X9, 7X7 veya 5X5) görüntüye uygulanır. Uygulanan filtrede ortadaki değer hariç diğer değerler -1, ortasındaki değer ise toplamı 0 yapmaya yetecek şekilde seçilir. Örneğin Tablo 1'de gösterildiği gibi $5 \times 5$ boyutunda filtrenin orta değeri 24 olarak alınır.

Tablo 1. 5 X5 boyutlarında filtre

\begin{tabular}{|c|c|c|c|c|}
\hline-1 & -1 & -1 & -1 & -1 \\
\hline-1 & -1 & -1 & -1 & -1 \\
\hline-1 & -1 & 24 & -1 & -1 \\
\hline-1 & -1 & -1 & -1 & -1 \\
\hline-1 & -1 & -1 & -1 & -1 \\
\hline
\end{tabular}

$\mathrm{Bu}$ filtrenin uygulanması ile yüksek geçiren değer elde edilmiş ve tüm bantlara uygulanması suretiyle de çözünürlük artırılmış olur. PAN bant ile MS bant arasındaki oran " $r$ " olarak alınır ise filtre boyutu " $2 r+1$ " olacaktır ki bu da Göktürk-1 uydu görüntüleri için 9X9 boyutlarında bir filtre uygulanması gerektiği anlamına gelir. Pankromatik bantta yüksek geçirgen süzgeçten geçirilerek elde edilen görüntünün MS görüntüdeki tüm bantlara uygulanması esasına dayanır. $\mathrm{Bu}$ yöntemde mekânsal bilginin kullanımı daha optimize edilmek amacıyla elde edilen keskinleştirilmiş bantlar orijinal görüntünün bantlarına göre normalize edilir. MS görüntüler pankromatik görüntüye göre ölçeklendirildikten sonra seçilmiş olan filtre ile keskin görüntü elde edilir. MS görüntüdeki bantlara göre elde edilen oran kullanılarak süzgeçten geçirilmiş görüntü normalize edilir. Ardından elde edilen görüntü ile MS görüntüdeki ölçeklendirilmiş bantlar birleştirilir. Ortaya çıkan renkli görüntü, orijinal MS görüntü ile standart sapması ve ortalaması eşitlenecek şekilde tekrar normalize edilir ve yüksek mekânsal çözünürlüklü renkli görüntü elde edilir.

\subsubsection{Gram-Schmidt yöntemi}

Gram-Schmidt yönteminde, IHS ve PCA yöntemlerinden farklı olarak tüm bantlara uygulanır ve MS görüntünün örnekleme yapılması suretiyle değil de MS görüntülerin ortalamasına göre PAN görüntünün çözünürlüğünün simüle edilmesi suretiyle elde edilen düşük çözünürlüklü PAN görüntünün ilk bant olarak kullanılmasından yola çıkılarak işlemlere başlanır.

$\operatorname{Pan}_{\text {sim }}=\sum_{k=1}^{n} w_{k} M S_{k}$

Simüle edilen pankromatik bandı ilk bant olarak kullanılır, simüle edilmiş bu ilk bant PAN ve MS bantlar üzerinde Gram-Schmidt dönüşümünün gerçekleştirilir. $\mathrm{Bu}$ işlem yapılırken bantların birbirine dik olmasına özen gösterilir, örneğin PAN bandın Kırmızı banda dik olmasını sağlayacak açı hesaplanarak bu kadar kaydırılır. Bu işlem sırası ile tüm bantlara uygulanır. Bu işlemler sonunda yüksek çözünürlüklü pankromatik görüntü bandı ilk GramSchmidt yönteminde elde edilen bant ile yer değiştirilir. Pankeskinleştirilmiş MS bantları oluşturmak için ters Gram-Schmidt dönüșüm uygulanır ve böylelikle pankeskinleştirilmiş görüntü elde edilir (Maruer, 2013).

\subsubsection{HSV (Hue Saturation Value) yöntemi}

Bu yöntemde de IHS yönteminde olduğu gibi yoğunluk renk doygunluk uzayı yerine renk doyum değeri uzayı kullanılır. MS görüntüsündeki bantlar HSV renk uzayına dönüştürüldükten sonra pankromatik bandındaki yüksek mekânsal görüntü ile birleştirilip keskinleştirilmiş görüntü elde edilir.

RGB renkler HSV uzayına dönüştürüldükten sonra HSV renk uzayındaki değer (value) yerine yüksek mekânsal çözünürlüğe sahip pankromatik görüntü yerleștirilir ve tekrar RGB renk uzayına dönüştürülür.
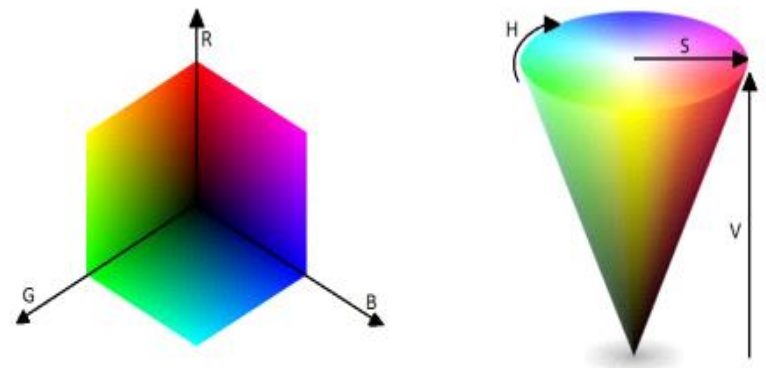

Şekil 10.RGB ve HSV renk-uzay grafikleri

Şekil 10'da görülen 3 eksenli renk uzayı koni biçimdeki HSV renk uzayına dönüştürüldüğünde koni yüksekliği rengin değerini temsil etmektedir. $\mathrm{Bu}$ değer yerine pankromatik görüntüden alınan değer yazılır ve böylece yüksek çözünürlüklü görüntü elde edilmiş olur.

\subsection{Kullanılan Matematiksel Ölçütler}

Görüntü birleştirme yöntemleri uygulanarak elde edilen görüntülerin başarısını ölçmek, yöntemleri karşılaştırabilmek ve çeşitli parametrik değerlerin etkisini görmek için kalite değerlendirme yöntemlerine ihtiyaç duyulmaktadır. Bu ihtiyacı karşılamak amacıyla bu çalışmada, literatürde kabul gören ve sıkça kullanılan beş adet değerlendirme yöntemi kullanılmıştır. Pankeşkinleştirme işlemi 
sonunda elde edilen görüntünün en kolay ve gözlemlenebilir değerlendirme ölçütü görsel değerlendirmedir. Ancak görsel olarak görüntüleri değerlendirme işlemi objektif yapılamamaktadır. Elde edilen görüntünün ne kadar keskin ya da ne kadar renkli olduğu değerlendirmeyi yapan kişiden kișiye farklılık gösterebilmektedir. Hatta görüntülerin birbirine çok yakın olduğu durumlarda görsel olarak kıyaslama yapmak nerede ise imkânsızdır. Ayrıca bazen görsel olarak iyi görünen görüntülerin orijinal renk değerlerine göre farklı değerleri barındırdığı gözlemlenmiștir. Kullanılan birleștirme kalite değerlendirme yöntemlerinde referans görüntü olarak Göktürk-1 MS görüntü, kalitesi hesaplanacak olan görüntü olarak ise Göktürk-1 PAN ve MS görüntülerinin görüntü birleştirme yöntemleri uygulanarak elde edilen pankeskinleştirilmiş görüntü kullanılmıștır. Elde edilen görüntüler yaygın olarak kullanılan ERGAS (Erreur Relative Globale Adimensionnelle de Synthèse) "Boyutsuz Global Göreli Sentez Hatası", RMSE (Root Mean Square Error) "Karesel Ortalama Hata", CC (Correlation Coefficient) "Bağllık Katsayısı" ya da "Korelasyon Katsayıs", RASE (Relative Average Spectral Error) "Göreceli Ortalama Spektral Hata” ve UIQI (Universal Image Quality Index; QAVE yani Q-ave(average) Ortalama Kalite) bir başka deyişle "Evrensel Görüntü Kalitesi İndeksi" olmak üzere 5 adet matematiksel ölçüt ile MATLAB yazılımı üzerinden değerlendirilmiştir. QAVE ve UIQI ölçütleri aynıdır literatürde ikisinin de kullanımı mevcuttur. Biz yaptı̆ımız analizler sonucunda oluşturduğumuz tablo ve grafiklerde QAVE ismini kullanacağız.

ERGAS: Bu ölçüt, Pankeskinleștirilmiş görüntüdeki bant değerlerinin yüksek çözünürlükten düşük çözünürlüğe geçerken ki kalitesini ölçer. ERGAS sonucu elde edilen değerler ne kadar küçük ise yani sıfıra ne kadar yaklaşır ise o kadar başarılı sayılır

$E R G A S=100 \frac{h}{l} \sqrt{\frac{1}{N} \sum_{i=1}^{N}\left(\frac{R M S E(n)}{\mu^{(n)}}\right)^{2}}$

Burada; N bant sayısını, RMSE karesel ortalama hatayl, $\frac{h}{l}$ PAN görüntüdeki piksel değerlerinin MS görüntüdeki piksel değerlere oranını, $\mu(n)$ ise $n$. bandın ortalamasını ifade etmektedir.

RMSE: “Karesel Ortalama Hata” (RMSE) MS görüntü ile pankeskinleştirilmiş görüntü arasındaki farkların karesel ortalama hatasını temel alan ölçüttür. Bu hesaplama sonucunda elde edilen değerler ne kadar küçük olursa birleştirme kalitesi o kadar başarılı olmuş demektir.

$R M S E=\sqrt{\frac{\sum_{x} \sum_{i}\left(X_{i}(x)-Y_{i}(y)\right)^{2}}{n x m x d}}$

Denklemde yer alan ifadelerden; “ $X$ ”, MS görüntüyü, "Y", pankeskinleștirme işlemi sonrasında elde edilen görüntüyü, "x" piksel indeksini, "i" bant numarasını göstermektedir. Bölen kısımda satır sayısı " $n$ " ile, sütun sayısı " $m$ " ile " $m$ " ile, bant sayısı "d" ile ifade edilmektedir. Referans değerin " 1 " olması beklenmektedir.

CC: Bu ölçüt, bağlılık katsayısı ya da korelasyon katsayısı olarak da adlandırılır. Ölçütün matematiksel ifadesi formül (17) da verilmiștir. Burada $\bar{X}$ ve $\bar{Y}$ sirasiyla MS görüntü ve pankeskinleștirilmiş görüntülerin ortalamasını ifade etmektedir. Bu eşitlik iki görüntü arasındaki bağlılık katsayısını ifade eder.

$$
C C(X, Y)=\frac{\sum_{m n}\left(X_{m n}-\bar{X}\right)\left(Y_{m n}-\bar{Y}\right)}{\sqrt{\left(\sum_{m n}\left(X_{m n}-\bar{X}\right)^{2}\left(Y_{m n}-\bar{Y}\right)^{2}\right)}}
$$

RASE: Bu ölçüt, Göreceli Ortalama Spektral Hata olarak da adlandırılır ve karesel ortalama hata yönteminden türetilmiştir. Bu ölçütün matematiksel büyüklüğü (18) eșitliğinde ifade edilmiştir.

$R A S E=100 \sqrt{\frac{1}{n} \sum_{i=1}^{n}\left(\frac{R M S E^{2}(i)}{G\left(M S_{i}\right)}\right.}$

Bu ifadede $G\left(\mathrm{M} S_{i}\right)$ ifadesi MS görüntünün $i$ 'inci bandı için algılayıcı kazanç değerini ifade etmektedir. $\mathrm{Bu}$ yöntem kullanılarak elde edilen değerler ne kadar küçük olursa, birleştirme kalitesi o kadar başarılı olur.

QAVE: Bu ölçüt, Q-ave yani Q-average - Ortalama Kalite ya da Evrensel Görüntü Kalitesi İndeksi (UIQI) olarak da adlandırılır. Bu ölçüt spektral bozulmayı üç etken açısından inceler. Bu etkenler ilinti kaybı, parlaklık bozulması ve kontrast bozulmasıdır.

$Q=\frac{4 \sigma_{x y} \bar{X} \bar{Y}}{\left(\sigma_{x}^{2}+\sigma_{y}^{2}\right)\left[(\bar{X})^{2}(\bar{Y})^{2}\right]}$

$x=\left\{x_{\mathrm{i}} \mid i=1,2, \ldots, N\right\}$ ve $y=\left\{y_{\mathrm{i}} \mid i=1,2, \ldots, N\right\}$ sirasiyla MS ve birleștirilmiş görüntü vektörlerini ifade etmektedir (Açıkgöz, 2015).

$$
\begin{aligned}
& \sigma_{x}^{2}=\frac{1}{N-1} \sum_{i=0}^{N}\left(x_{i}-\bar{x}\right)^{2} \\
& \sigma_{y}^{2}=\frac{1}{N-1} \sum_{i=0}^{N}\left(y_{i}-\bar{y}\right)^{2} \\
& Q_{x y}=\frac{1}{N-1} \sum_{i=1}^{N}\left(x_{i}-\bar{x}\right)\left(y_{i}-\bar{y}\right)
\end{aligned}
$$

UIQI metriği bir başka değişle görüntüdeki korelasyon kaybının, parlaklık değişiminin ve kontrast değişiminin birleştirilmiş modeli olarak tanımlanmıştır. (Abdikan, 2017).

\section{BULGULAR VE DEĞERLENDİRME}

\subsection{Bulgular}

Görsel sonuçların gösterimi için Şekil 11'de görülebileceği üzere Anıtkabir bölgesi (Ankara) 
kullanılmıștır. PAN ve MS görüntü ile birlikte pankeskinleștirme sonucunda elde edilen görüntüler Şekil 12'de sunulmuştur.

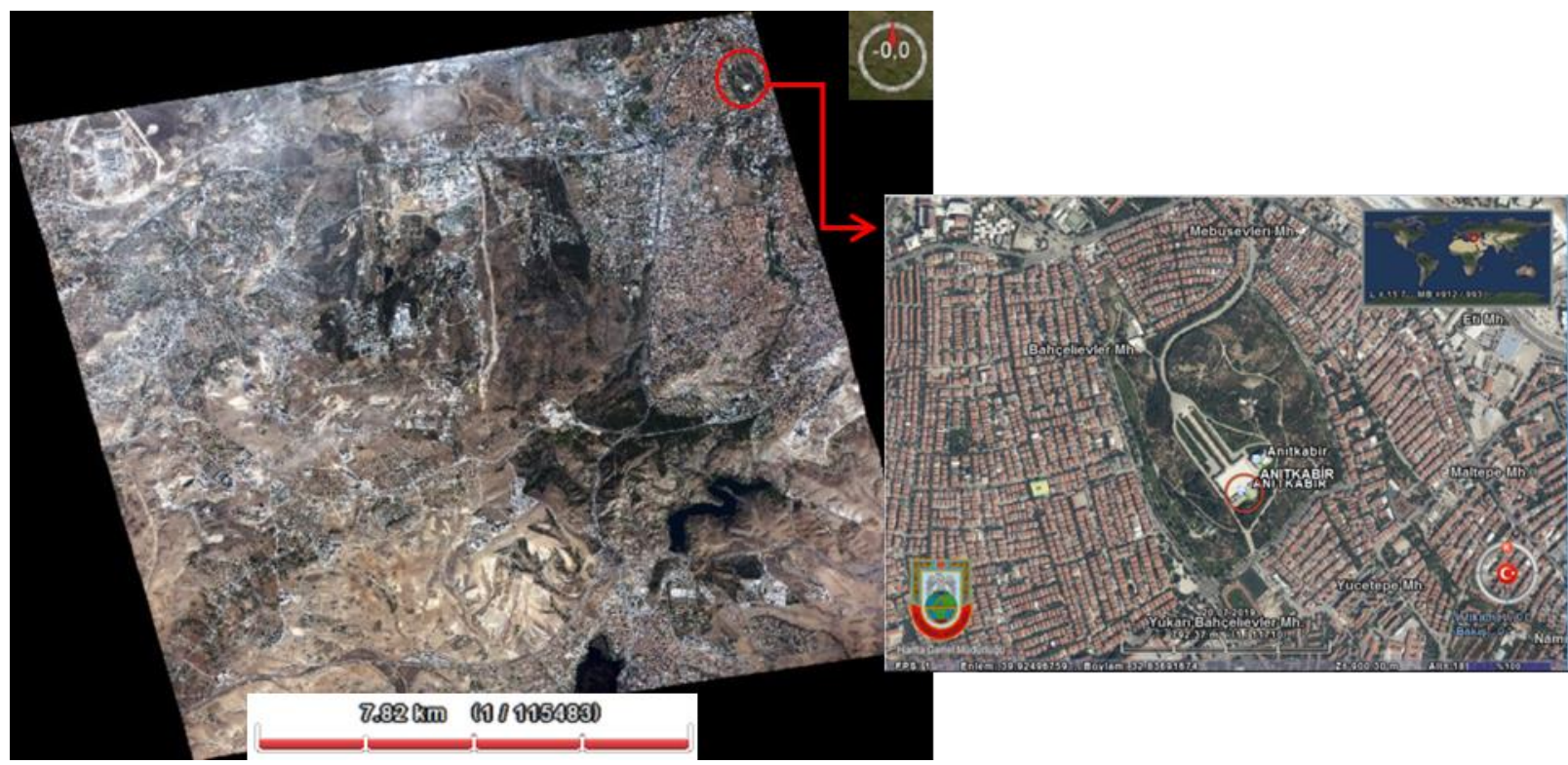

Şekil 11.Görüntünün tamamı ve görsel olarak kullanılan alan

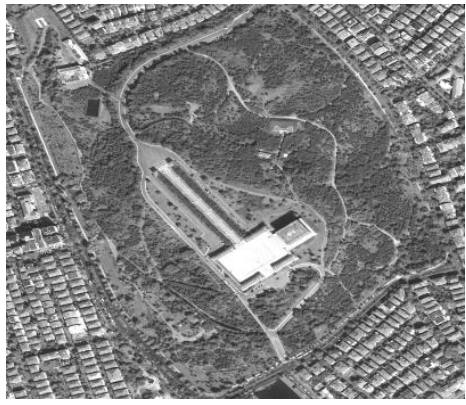

(a)

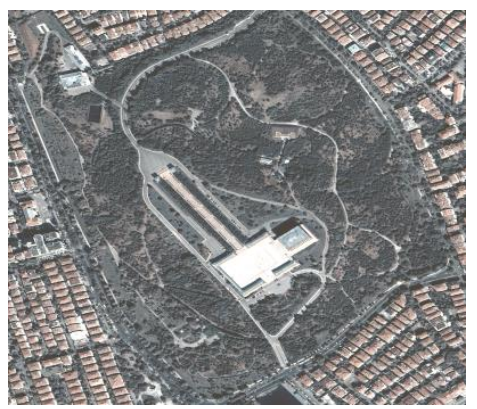

(ç)

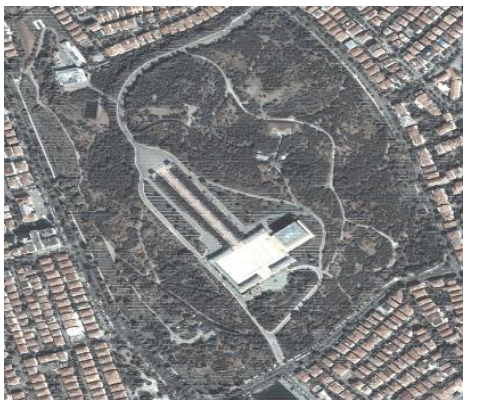

(f)

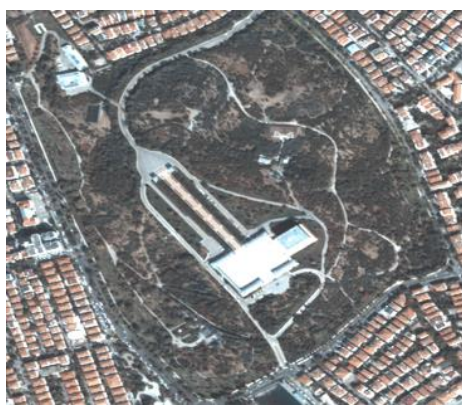

(b)

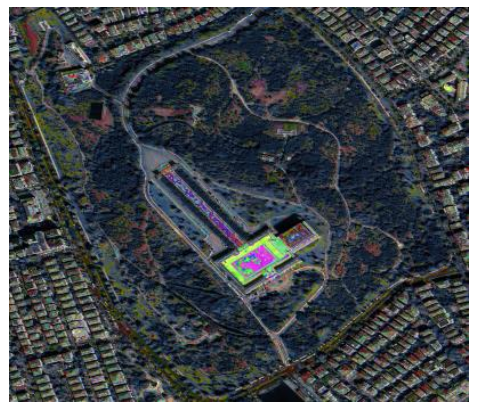

(d)

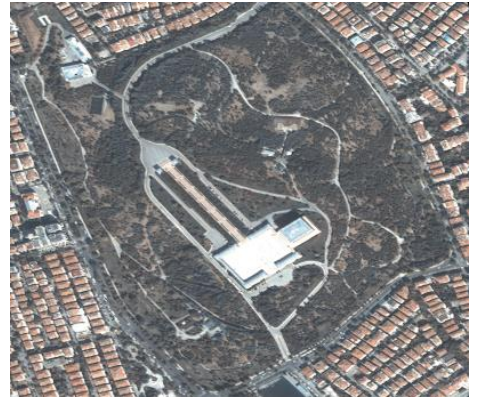

(g)

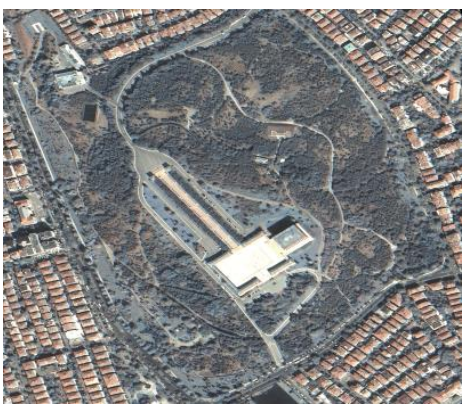

(c)

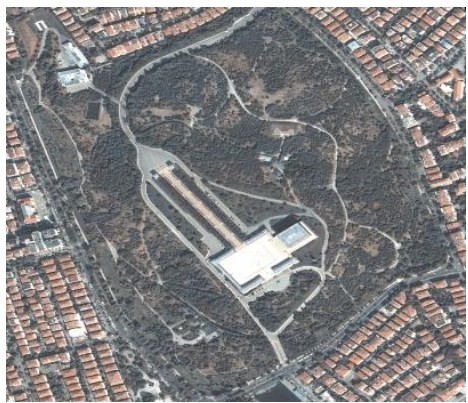

(e)

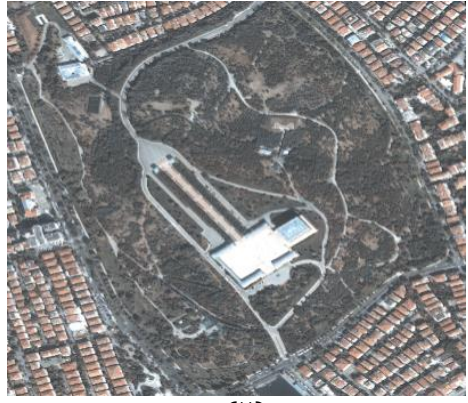

( $\breve{\mathrm{g}})$ 


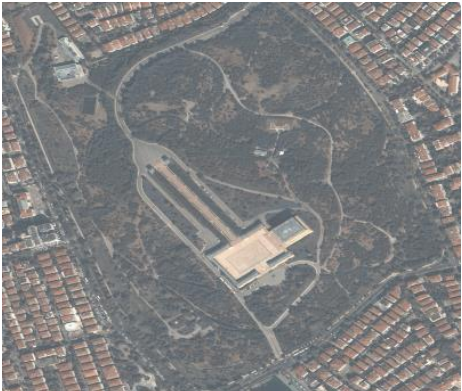

(h)

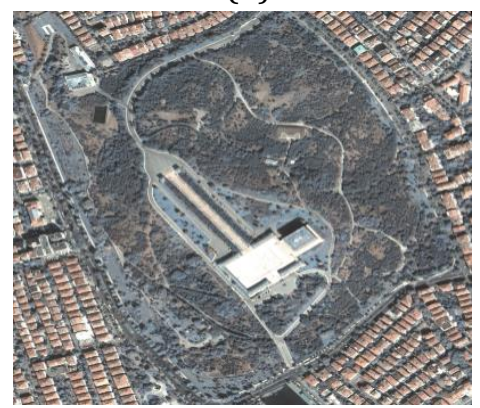

(j)

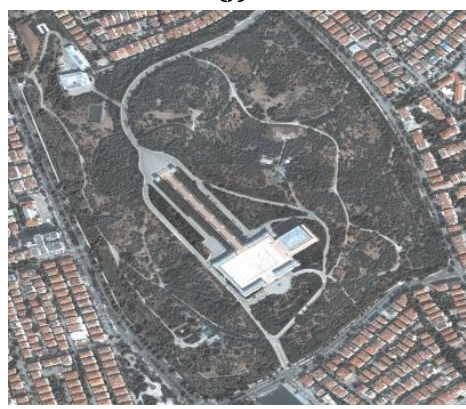

(m)

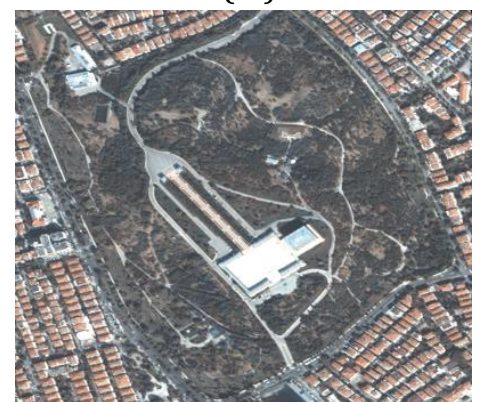

(ö)

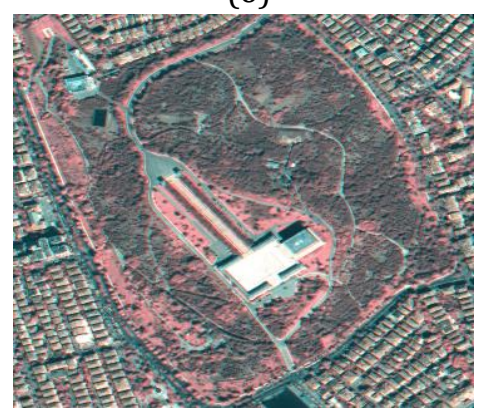

(s)

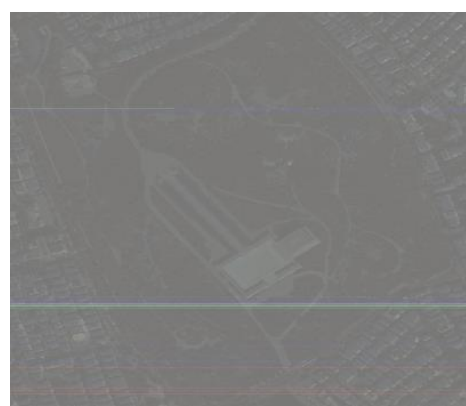

(1)

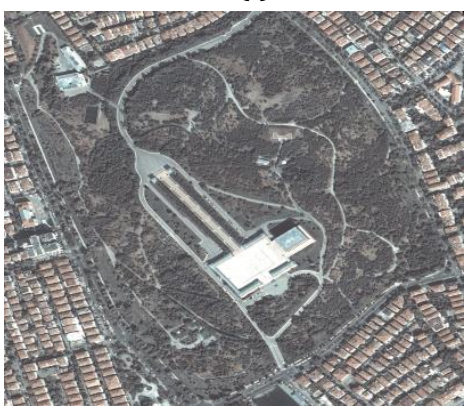

(k)

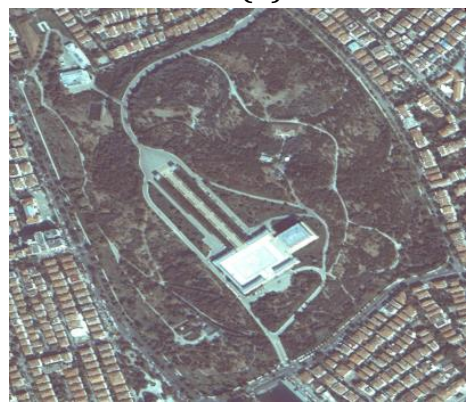

(n)

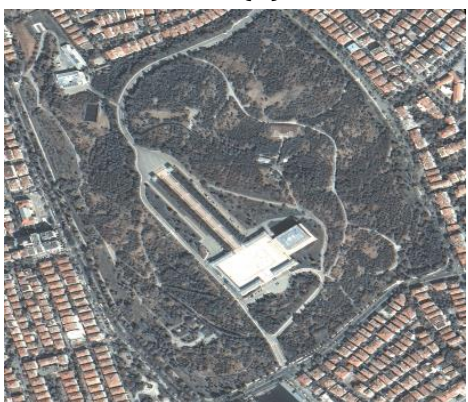

(p)

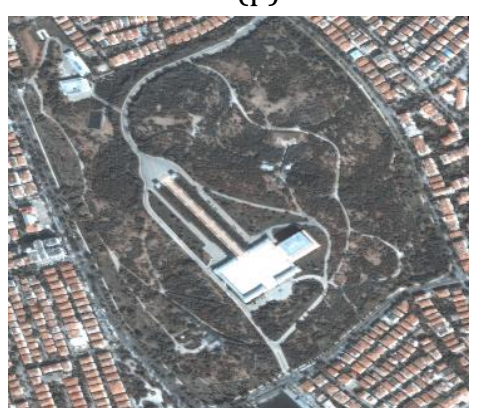

(s)

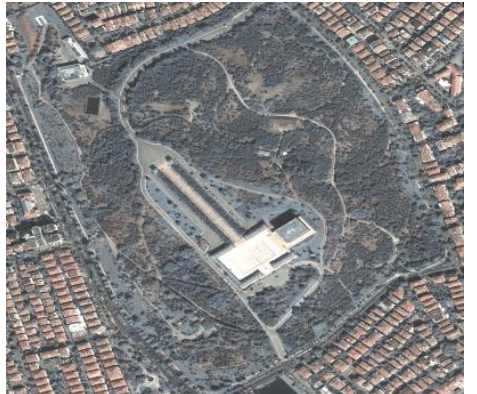

(i)

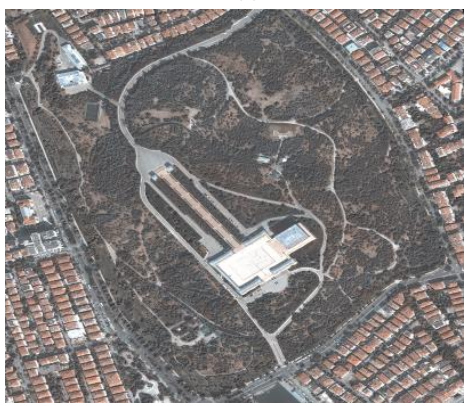

(l)

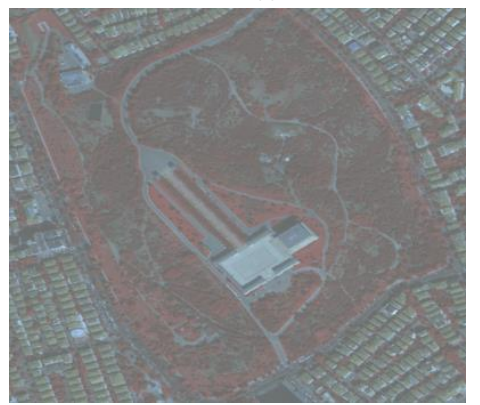

(o)

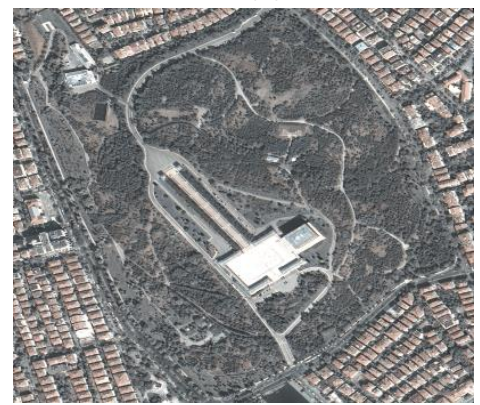

(r)

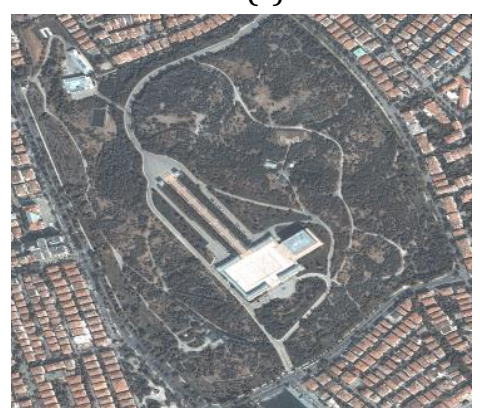

(t) 


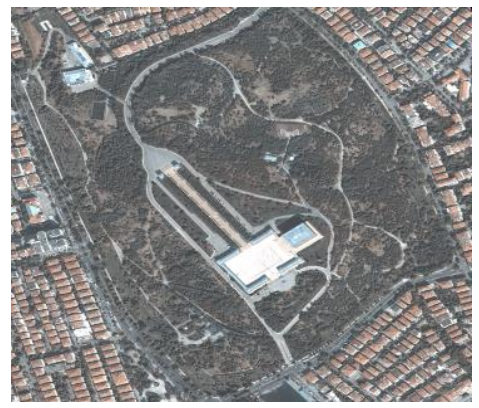

(u)

Şekil 12.a) PAN b) MS c) ENVI - Color Normalized Brovey c) ENVI - Gram Schmidt d) ENVI - HSV e) ENVI NNDiffuse f) ENVI - PC Pansharpening g) ERDAS - HCS Resolution Merge $\breve{g}$ ) ERDAS - HPF Resolution Merge h) ERDAS - Modified IHS Resolution Merge 1) ERDAS - NNDiffuse i) ERDAS - Projective Resolution Merge j) ERDAS Resolution Merge Brovey k) ERDAS - Resolution Merge PCA l) ERDAS - Subtractive Resolution Merge m) ERDAS Subtractive Resolution Merge - Legacy n) ERDAS - Wavelet Resolution Merge IHS o) ERDAS - Wavelet Resolution Merge Single Band ö) ERDAS - Wavelet Resolution Merge PC p) HASAT - Brovey r) HASAT - Esri s) HASAT - IHS ş) PCI - MRA t) PCI - PANSHARP u) PCI - UNB

Tüm yöntemler için elde edilen sonuçlar Tablo 2'de sunulmuștur. Farklı programlarda bulunan farklı algoritmalarla elde edilen pankeskinleștirilmiş görüntüler MATLAB programında açık kaynaklarda kolaylıkla bulunabilinen ve en çok kullanılan metrik yöntemlerle kıyaslanmıştır.

Tablo 2. Matematiksel ölçütler sonucu elde edilen bulgular

\begin{tabular}{|c|c|c|c|c|c|}
\hline & ERGAS & RMSE & $\mathbf{C C}$ & RASE & QAVE \\
\hline Referans Değer & 0 & 1 & 1 & 1 & 1 \\
\hline ENVI - CN Brovey & 0,718905 & 287,1068 & 0,718905 & 52,53389 & 0,544562 \\
\hline ENVI - Gram Shmidt & 12,70875 & 235,0328 & 0,838463 & 50,835 & 0,794311 \\
\hline ENVI - HSV & 46,76136 & 511,329 & 0,526591 & 93,52272 & 0,062528 \\
\hline ENVI - NNDiffuse & 6,726921 & 124,6372 & 0,951297 & 26,90769 & 0,942416 \\
\hline ENVI - PC Pansharpening & 5,103709 & 94,46666 & 0,960671 & 20,41484 & 0,960669 \\
\hline ERDAS-HCSResolution Merge & 4,978923 & 92,25477 & 0,964394 & 19,91569 & 0,963976 \\
\hline ERDAS - HPF Resolution Merge & 5,386647 & 99,83811 & 0,959467 & 21,54659 & 0,953767 \\
\hline ERDAS-Modi IHS Resolution Merge & 18,07936 & 197,202 & 0,608661 & 36,15871 & 0,577839 \\
\hline ERDAS-NNDiffuse & 1978,621 & 36292,16 & $-0,84525$ & 7914,485 & $-0,00085$ \\
\hline ERDAS-Projective Resolution Merge & 26,98317 & 295,0096 & 0,615377 & 53,96635 & 0,492526 \\
\hline ERDAS-Resolution Merge Brovey & 26,15847 & 286,0085 & 0,723664 & 52,31693 & 0,549724 \\
\hline ERDAS - Resolution Merge PCA & 10,51012 & 194,6094 & 0,949002 & 42,0405 & 0,896366 \\
\hline ERDAS-Subtractive Resolution - Merge & 6,94250 & 127,3270 & 0,933099 & 27,94891 & 0,932145 \\
\hline ERDAS-Subtractive Resolution Merge_Legacy & 6,558653 & 121,5391 & 0,938786 & 26,23461 & 0,937948 \\
\hline ERDAS - Wavelet IHS & 9,108943 & 99,70032 & 0,867044 & 18,21789 & 0,858441 \\
\hline ERDAS-Wavelet Resolution Merge SinglenBand & 19,70675 & 208,3006 & 0,723197 & 39,4135 & 0,675317 \\
\hline ERDAS-Wavelet Resolution Merge PC & 9,040227 & 98,39511 & 0,873338 & 18,08045 & 0,865941 \\
\hline HASAT - Brovey & 19,64463 & 363,8174 & 0,949506 & 78,57851 & 0,417672 \\
\hline HASAT - Esri & 17,408 & 318,5911 & 0,946895 & 69,63199 & 0,798957 \\
\hline HASAT - IHS & 13,71271 & 275,344 & 0,941968 & 54,85086 & 0,922434 \\
\hline PCI - MRA & 4,20269 & 77,77741 & 0,973583 & 16,81076 & 0,973554 \\
\hline PCI-Pansharp & 6,819101 & 126,294 & 0,930293 & 27,2764 & 0,930291 \\
\hline PCI-UNB (Pansharp2) & 5,794949 & 107,3482 & 0,949371 & 23,1798 & 0,94937 \\
\hline
\end{tabular}


Edilen sonuçlara göre, ERDAS NNDiffuse yönteminde elde edilen bulgularda kaba hata olduğu kabul edilebilir. Kaba hatalı oluğu değerlendirilen yöntem matematiksel ölçütlerden çıarıldıktan sonraki grafikler Şekil 13'de sunulmuştur.
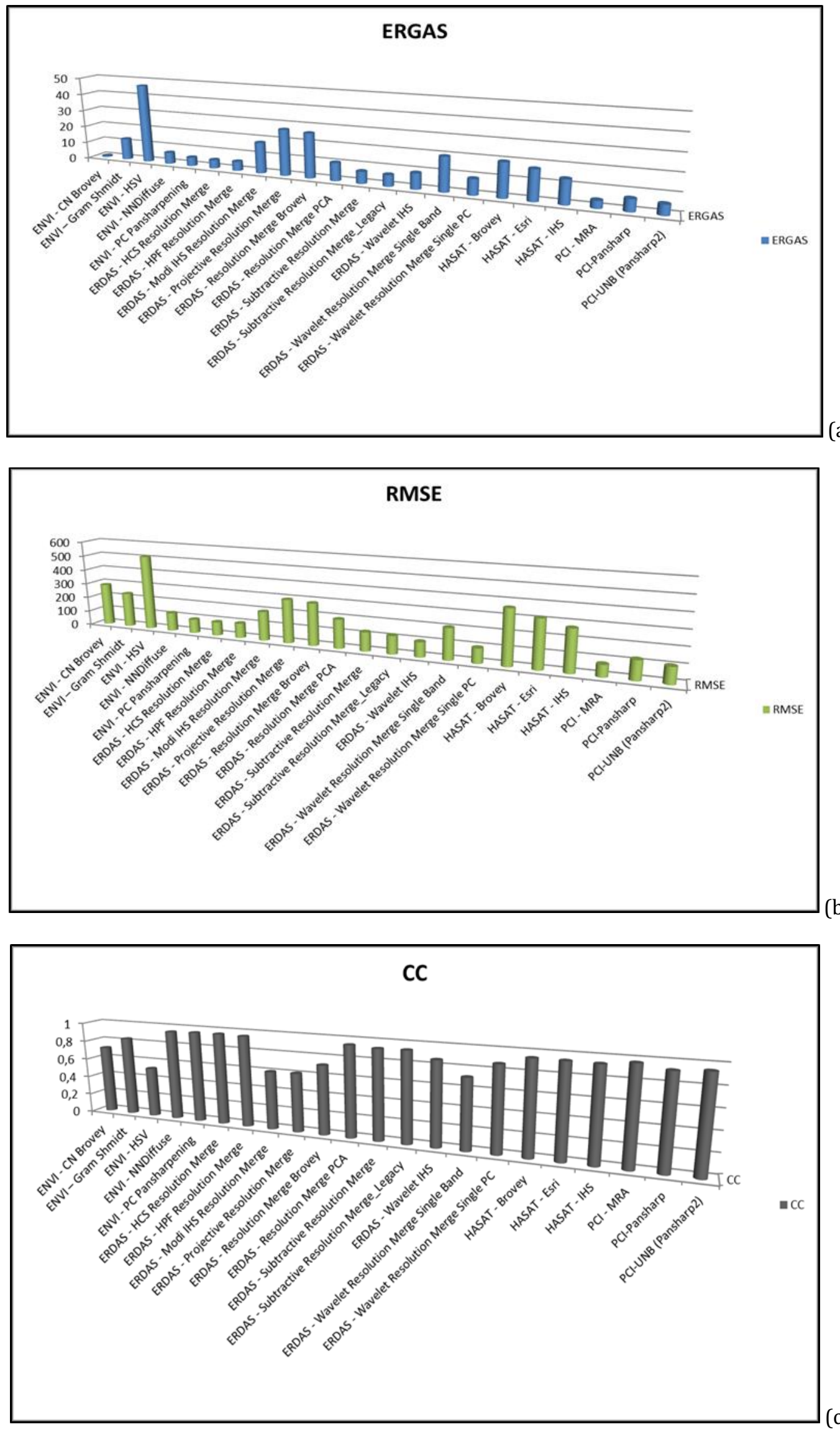

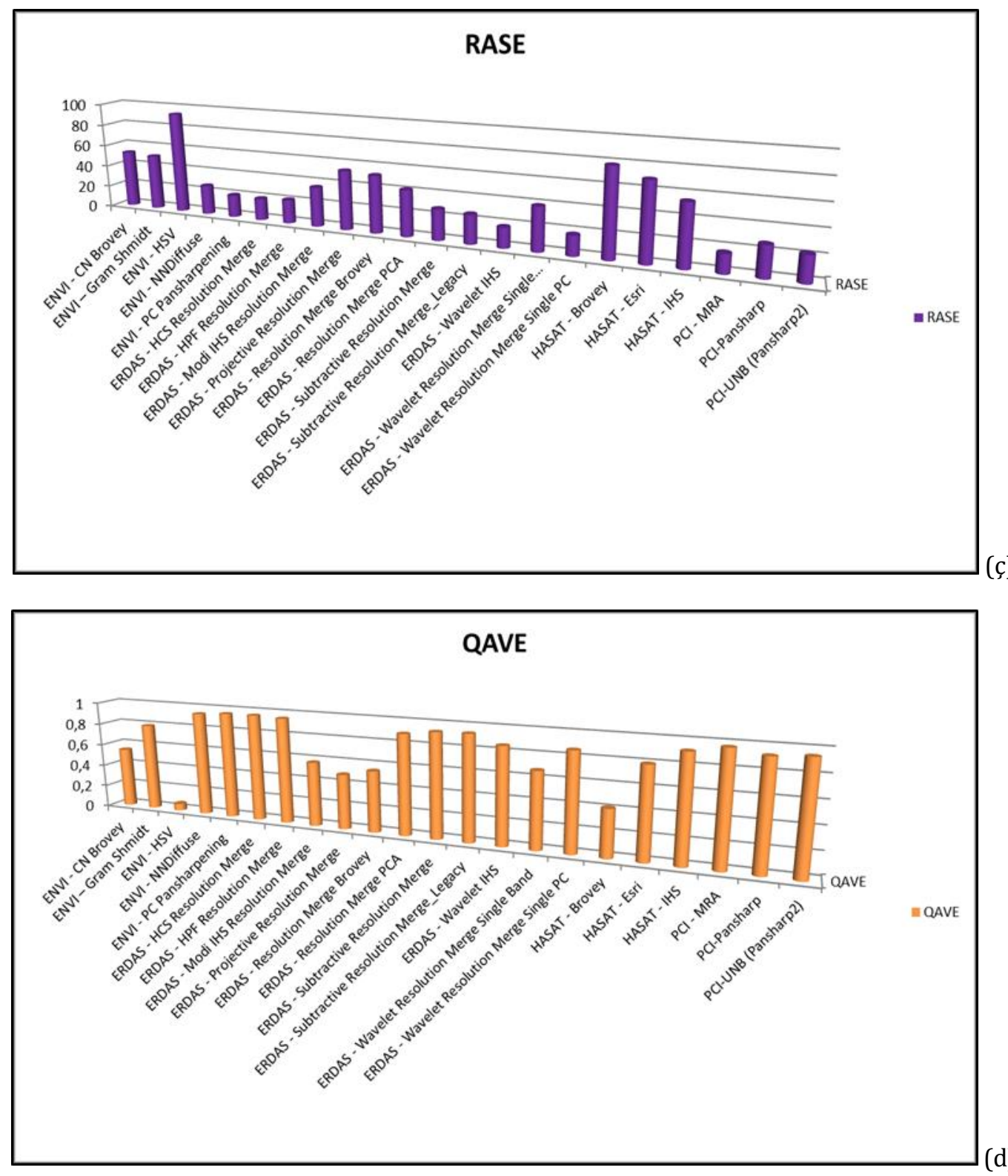

(d)

Şekil 13.(a-d) Hatalı ERDAS NNDiffuse sonuçları atıldıktan sonraki metrik sonuçlar

Yazılımların metrik sonuç seçenekleri içerisinde ayrı bir değerlendirme yapacak olursak;

QAVE metriğinde; "ENVI - HSV Resolution Merge", RASE metriğinde; "ENVI - HSV Resolution Merge" ve HASAT yazılımı ile pankeskinleştirilen görüntüler, CC metriğinde; "ENVI - HSV Resolution Merge", "ERDAS Modified IHS Resolution Merge" ve "ERDAS Projective Resolution Merge", RMSE metriğinde; "ENVI - HSV Resolution Merge", "HASAT - ESRI ve Brovey" ve "ERDAS Projective Resolution Merge", ERGAS metriğinde; "ENVI - HSV Resolution Merge", "ERDAS Projective Resolution Merge" ve "ERDAS Projective Resolution Merge" yöntemleri ile elde edilen görüntüler başarısız sonuçlar vermiştir.

\subsection{Değerlendirme}

Görsel olarak görüntüleri klyaslamak kişiden kişiye mutlaka farklılıklar gösterecektir. Görüntüler arasındaki en iyi görüntüyü seçmek uzmanlık gerektirir. Göktürk-1 uydu görüntüleri için kullanılan her yazılım içerisinden bir ya da birden çok algoritmanın iyi sonuç verdiği ortaya konulmuştur. Değerlendirmeler görsel ve metrik olarak iki kısımda özetlenebilir.

\subsubsection{Görsel değerlendirme}

ENVI yazılımı ile yapılan pankeskinleștirme sonuçlarına göre en güzel sonucun "NNDiffuse Pan Sharpening" yöntemi ile elde edilen görüntü olduğu açıktır. ENVI'de kullanılan "Gram Schmidt Pan Sharpening" algoritması da diğerlerine göre güzel sonuç vermiștir. ENVI "HSV Sharpening" algoritması ile elde edilen pankeskinleştirilmiş görüntünün hatalı çıktığı değerlendirilmektedir.

ERDAS yazılımı ile 12 adet pankeskinleştirilmiş görüntü elde edilmiş, "NNDiffuse Resolution Merge" algoritmasının hatalı sonuç verdiği değerlendirilmiștir. Ayrıca ERDAS "Wavelet Resolution Merge - Single Band" metodu ile elde edilen görüntü hatalı sonuç vermiştir. ERDAS 
"Modified İHS Resolution Merge" yöntemi ile elde edilen görüntü ile ERDAS "Wavelet Resolution Merge - IHS” yöntemi ile elde edilen görüntüler puslu ya da yeterince net değildir. ERDAS yazılımı için "HCS Resolution Merge", "HPF Resolution Merge", "Resolution Merge - PCA", "Subtractive Resolution Merge" ve "Subtractive Resolution Merge-Legacy" algoritmaları güzel sonuçlar vermiștir.

HASAT yazılımı IHS algoritmasının düzgün sonuç vermediği, Brovey ve ESRI algoritmalarının performanslı çalıştığı ve Brovey yöntemi ile elde edilen görüntünün diğerlerine göre daha yüksek doğrulukla sonuçlar verdiği değerlendirilmiştir.

PCI yazılımı ile yapılan pankeskinleştirme sonuçlarının tamamının başarılı sonuçlar verdiği bunlar içerisinde UNB algoritmasından elde edilen görüntünün diğerlerine klyasla daha iyi olduğu değerlendirilmektedir.

\subsubsection{Metrik değerlendirme}

Tüm metrikler içerisinde ERGAS metriğine göre; "ENVI Color Normalized (Brovey) Sharpening" yönteminin, RMSE, CC, RASE ve QAVE metriklerine göre; "PCI-MRA" yönteminin daha başarılı sonuçlar verdiği gözlenmiştir.

ERDAS yazılımı için metrik sonuçlar Şekil 14'de gösterilmektedir. ERDAS yazılımı ile elde edilen pankeskinleştirilmiş görüntüler içerisinde "HCS Resolution Merge" yöntemi ile keskinleştirilen görüntünün ERGAS, RMSE, CC ve QAVE metriklerine göre başarılı sonuç verdiği, RASE metriğinde ise "Wavelet Resolution Merge - PC" yönteminin diğerlerine göre daha iyi sonuç verdiği gözlemlenmiştir.

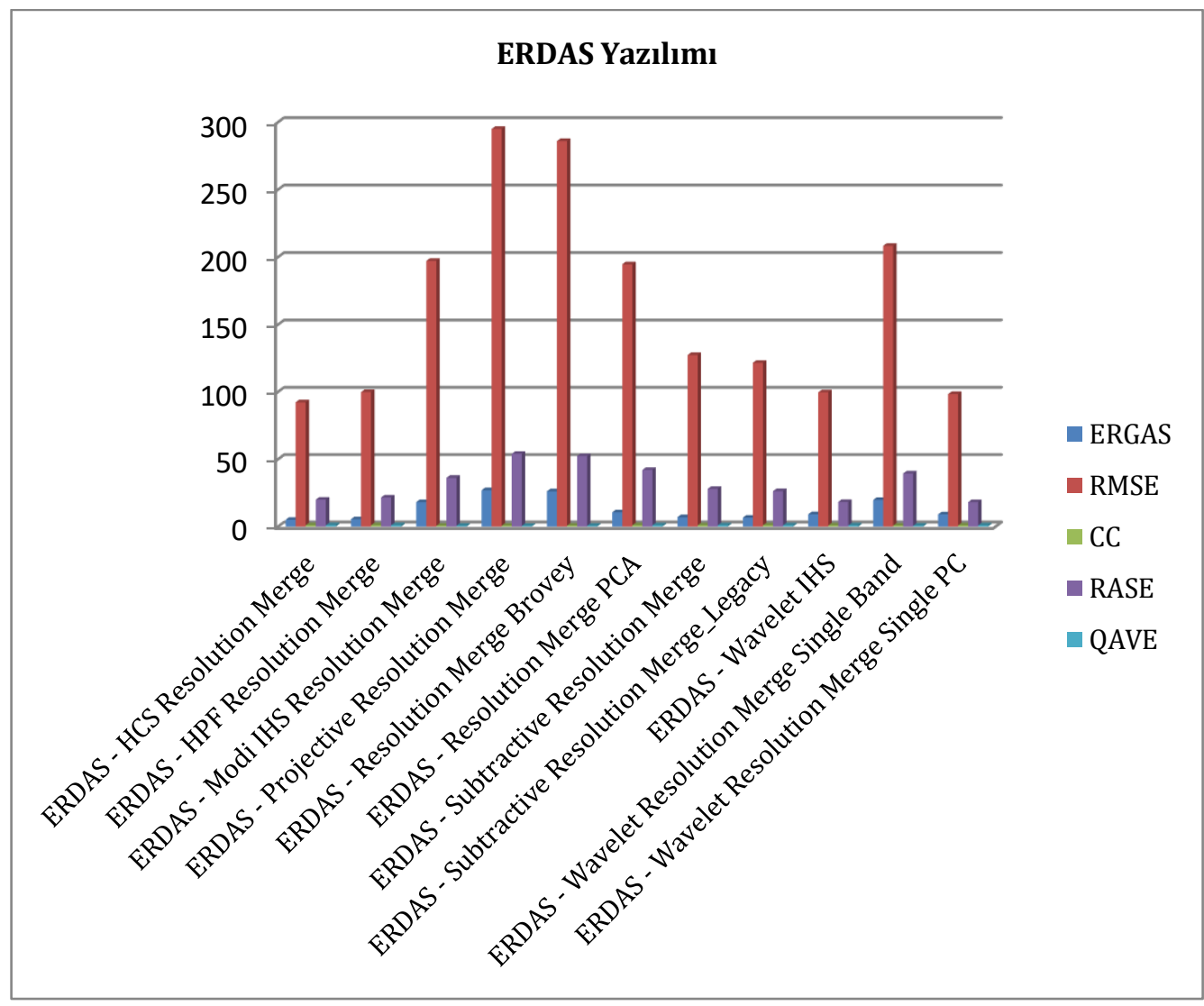

Şekil 14. ERDAS yazılımı değerlendirme grafiği

ENVI yazılımı için metrik sonuçlar Şekil 15'de gösterilmektedir. ENVI yazılımı ile elde edilen pankeskinleștirilmiş görüntüler içerisinde "ENVI Color Normalized (Brovey) Sharpening" yöntemi ile elde edilen görüntünün ERGAS metriğinde iyi sonucu verdiği, "ENVI PC Spectral Sharpening" yöntemi ile elde edilen görüntünün ise RMSE, CC,

RASE ve QAVE metriklerinde diğerlerine göre en iyi sonuçları verdiği anlaşılmaktadır. 


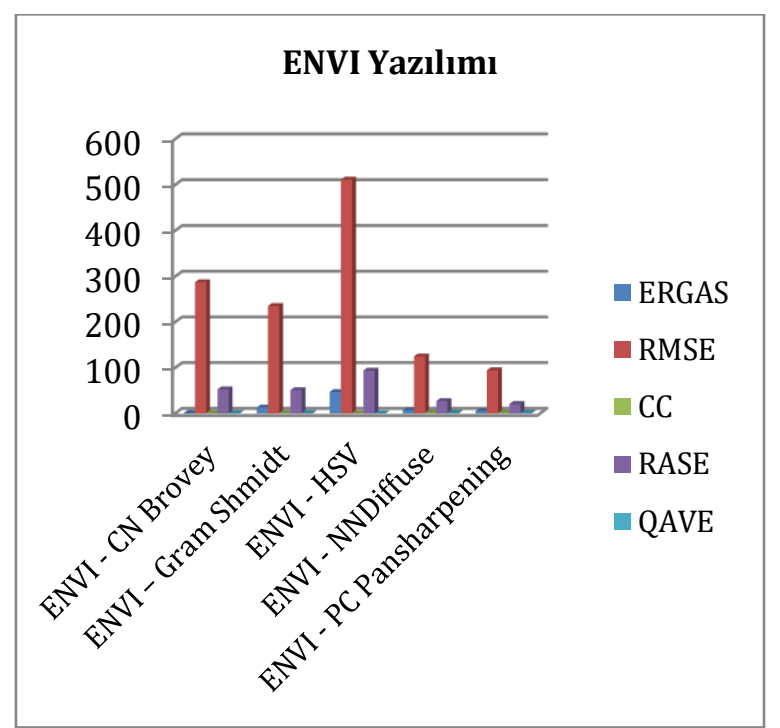

Şekil 15. ENVI yazılımı değerlendirme grafiği

PCI Geomatica yazılımı için metrik sonuçlar Şekil 16'da gösterilmektedir. PCI yazılımı ile pankeskinleștirilen görüntüler içerisinde RMSE, ERGAS, CC, RASE ve QAVE metriklerine göre PCIMRA yönteminin daha iyi sonuçlar verdiği görülmüştür.

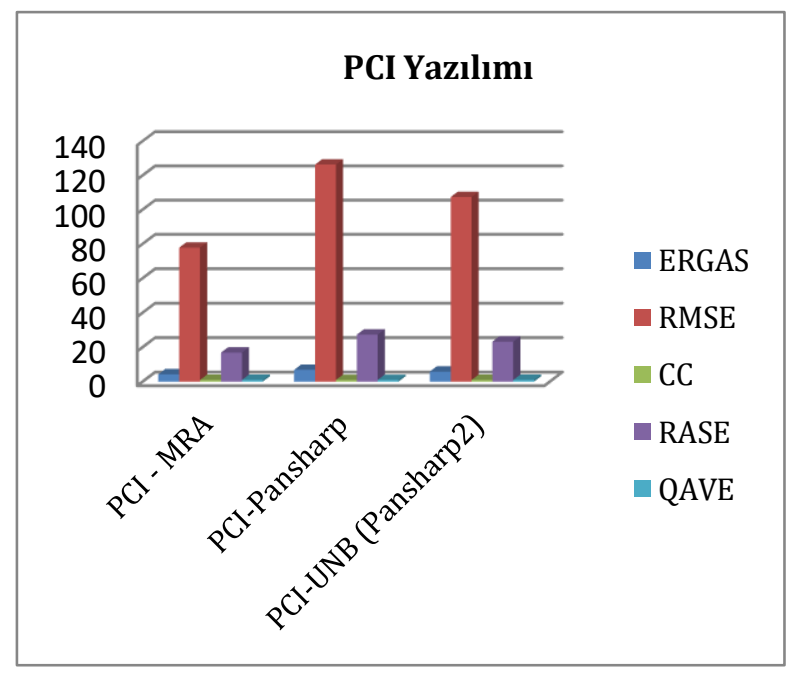

Şekil 16. PCI yazılımı değerlendirme grafiği

HASAT yazılımı için metrik sonuçlar Şekil 17'de gösterilmektedir HASAT yazılımı ile pankeskinleştirilen görüntüler içerisinde CC metriğine göre "HASAT-Brovey" yöntemi ile pankeskinleştirilen görüntü diğerlerine gmre daha iyi sonuç verirken ERGAS, RMSE, RASE ve QAVE metriklerine göre "HASAT - IHS" yöntemi ile elde edilen görüntü daha iyi sonuçlar vermiştir.

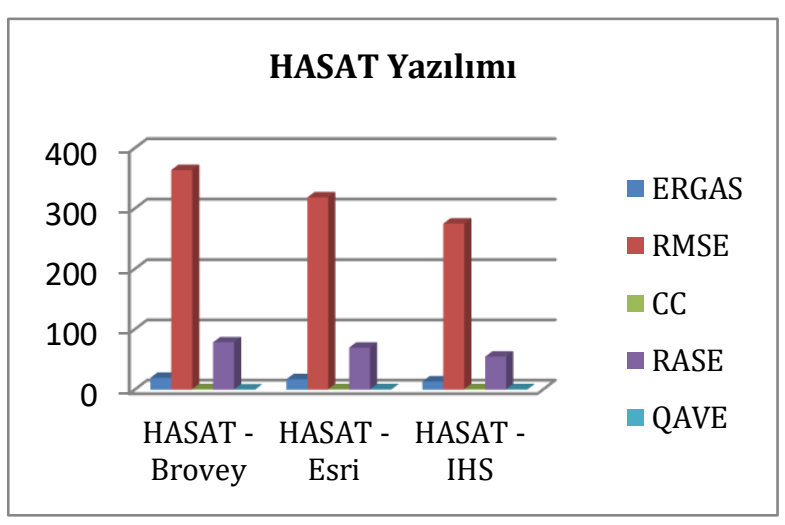

Şekil 17. HASAT yazılımı değerlendirme grafiği

\section{SONUÇ}

Göktürk-1 uydu görüntülerinin pankeskinleştirilmesi için bir öneri verilmeye çalıșılmıștır. $\mathrm{Bu}$ çalıșmanın sonuçlarından da anlaşılacağı üzere kullanılacak yazılımın performansı farklılıklar gösterebilir. Ayrıca Spot uydu görüntü alanının $(15 \mathrm{~km} * 15 \mathrm{~km})$ kapsadığı sahanın türü de (meskûn saha, ormanlık saha, suyla kaplı alan, toprak kaplı saha vs.) yazılımın ve kullanılacak pankeskinleștirme algoritmasının belirlenmesinde etken olmaktadır. Kullanılacak yazılımın aynı algoritmalar üzerindeki performansı bu çalışmadan da görüleceği üzere farklılık arz edebilir. Örneğin Brovey algoritması ile pankeskinleștirilen görüntü ENVI, ERDAS ve HASAT'da farklılıklar göstermiştir. Bunun nedeni firmalar tarafından ilgili algoritmaların yanında çeșitli filtrelerin alt programlara ilave edilmiș olmasıdır. Pankeskinleștirme işlemini uygulamadan önce ilgili uydu görüntüsü (Göktürk-1, Pleiades, Worldview vs.) üzerinde hangi filtreler uygulandığında güzel sonuçlar verdiği, hangi algoritmalarla pankeskinleştirilmesi gerektiği konularında daha önceden yapılmış olan çalışmalara göz atılması gerekmektedir. Göktürk-1 uydu görüntülerini pankeskinleştirmek için elinizde bulunan programa türüne göre ERDAS Imagine yazılıminda ERDAS Resolution Merge, Subtractive Resolution Merge ya da HCS Resolution Merge, ENVI yazılımında NNDiffuse Pan Sharpening, HASAT yazılımında Brovey ve PCI Geomatica yazılımında UNB (PANSHARP2) sekmelerinin kullanılmasının doğru olacağ sonucuna varılabilir.

\section{BILLILENDIRME/TEŞEKKÜR}

Makalenin ortaya çıkarılmasında bilgi birikim ve tecrübelerini sürekli paylaşan komutanlarım Dr.Müh.Alb.Veysel Okan ATAK'a ve Alb.Fatih Güven GÜLTEKIN'e, saygıdeğer hocam Prof.Dr.Ferruh YILDIZ'a, metrik ölçütleri yapmamda MATLAB yazılımı konusunda desteğini gördüğüm sayın Saygin ABDİKAN hocama ve her zaman manevi desteğini esirgemeyen eșim Gönül SEFER ÜNAL ve oğlum Atahan ÜNAL'a teșekkürü bir borç bilirim. 


\section{KAYNAKÇA}

Abas, A. (2015). Uzaktan Algllama Sistemlerinde Görüntü Füzyonu. TUFUAB VIII.Teknik Sempozyumu, (s. 183-189), Konya.

Abdikan, S. (2014). A comparative data-fusion analysis of multi sensor satellite images.Int.J Digital Earth, 671-687

Abdikan, S. (2017). Rasat Verisi Kullanarak Farklı Pan-Keskinleștirme Yöntemlerinin İstatistiksel Analizi. Türk Coğrafya Dergisi, 57-62.

Açıkgöz, İ. S. (2015). Uydu Görüntülerinin Pan Keskinleștirilmesi ve Performans Analizi. Ankara.

Ayhan, E. (2014). Uzaktan Algllamada Görüntü Birleștirme için Kalite Analizleri. 5. UZAKTAN ALGILAMA-CBS SEMPOZYUMU (UZAL-CBS 2014), İstanbul.

Basaeed, E. (2013). Comparative Analysis of Pansharpening Techniques on DubaiSat-1 images. 16th International Conference Information Fusion(FUSION).

www.researchgate.net/publication/26134.

Czaja, W. (2014). Wavelet Packet Mixing for Image Fusion And Pan-Sharpening. Conference Proceeding of SPIE (Society of Photo-Optical Instrumentation Engineers).

Despini, F. (2016). Methods and metrics for the assessment of Pan-sharpening algorithms.

Gore, S. A. (2016). A Comparative Analysis of Pansharpening Techniques on QuickBird and WorldView-3 Images. Geocarto International.

Gürçay, E. (2019). Göktürk-1 Uydusu Radyometrik ve Geometrik Kalibrasyon Faaliyetleri. Hava Kuvvetleri Dergisi,Ankara.

Gültekin, F.G.(2019). Geometric Accuracy in Satellite Imagery-Test Methods\&Göktürk-1 Performance Evaluation, RAST 2019 g $^{\text {th }}$ International Conference on Recent Advenges in Space Tecnologies.

Kahraman, S. (2017). A Comprehensive Review Of Pansharpening Algorithms For Göktürk-2 Satellite Images. ISPRS Annals of the Photogrammetry, Remote Sensing and Spatial
Information Sciences, ISPRS, Volume IV-4/W4, 2017 (s. 263-270), Karabük.

Maruer, T. (2013). How To Pan-Sharpen Images Using TheGram-Schmidt Pan-Sharpen MethodA Recipe. International Archives of the Photogrammetry, Remote Sensing and Spatial Information Sciences, (s. 239-244). Hannover: ISPRS.

Özdemir, M. (2017). Görüntü Keskinleștirme Yöntemlerinin Nesne-Yöneliml iSınıflandırma Açısından Değerlendirilmesi (Evaluation ofImage Pan-Sharpening Methods In Terms of Object-Oriented Classification). HARITA DERGISII, s. 26-34.

Özendi, M. (2014). Pleiades-1A Görüntülerinin PanSharpening Performansının İncelenmesi. 5. Uzaktan Algilama-CBS Sempozyumu. UZAL-CBS, İstanbul

Özendi, M., Topan, H., Oruc, M. ve Cam, A. (2015). "Pan-sharpeningquality investigation of PLÉIADES-1A images", Geocarto International, Taylor \& Francis GroupDOI: 10.1080/10106049.2015.1094520.

Parente, C. (2017). Influence of the weights in IHS and Brovey methods for pan-sharpening WorldView-3 satellite images. International Journal of Engineering \& Technology, s. 71-77.

Snehmani A., Ashwagosh G., Satish K., Srivastava P.K., ve Hari Ram R.P. (2016). A comparative analysis of pansharpening techniques on QuickBird and WorldView-3, Geocarto InternationalTaylor \& Francis GroupDOI: 10.1080/10106049.2016.1206627.

Sümengen, S. (2012). Yüksek Çözünürlüklü Uydu Görüntüler için Pankromatik Keskinleștirme Yöntemi. HAVELSAN A.Ş.

Teke, M. (2014). RASAT Uydu Görüntülerinin Optimal Pankeskinleștirilmesi. Ankara: TÜBİTAK UZAY.

Topan, H. (2016). Pleiades Project: Assessment Of Georeferencing Accuracy, Image Quality, Pansharpening Performence And DSM/DTM Quality. The International Archives of the Photogrammetry, Remote Sensing and Spatial Information Sciences, Volume XLI-B1, 2016 (s. 503-510). Prague: ISPRS. 